\title{
Increased Hippocampal Neurogenesis and Accelerated Response to Antidepressants in Mice with Specific Deletion of CREB in the Hippocampus: Role of cAMP Response-Element Modulator $\tau$
}

\author{
Brigitta B. Gundersen, ${ }^{1}$ Lisa A. Briand, ${ }^{1}$ Jennifer L. Onksen, ${ }^{1}$ John LeLay, ${ }^{2}$ Klaus H. Kaestner, ${ }^{2}$ and Julie A. Blendy ${ }^{1}$ \\ Departments of ${ }^{1}$ Pharmacology and ${ }^{2}$ Genetics, University of Pennsylvania School of Medicine, Philadelphia, Pennsylvania 19104
}

The transcription factor cAMP response element-binding protein (CREB) has been implicated in the pathophysiology of depression as well as in the efficacy of antidepressant treatment. However, altering CREB levels appears to have differing effects on anxiety- and depression-related behaviors, depending on which brain region is examined. Furthermore, many manipulations of CREB lead to corresponding changes in other CREB family proteins, and the impact of these changes has been largely ignored. To further investigate the region-specific importance of CREB in depression-related behavior and antidepressant response, we used $\mathrm{Creb}^{\text {loxPlloxP}}$ mice to localize CREB deletion to the hippocampus. In an assay sensitive to chronic antidepressant response, the novelty-induced hypophagia procedure, hippocampal CREB deletion, did not alter the response to chronic antidepressant treatment. In contrast, mice with hippocampal CREB deletion responded to acute antidepressant treatment in this task, and this accelerated response was accompanied by an increase in hippocampal neurogenesis. Upregulation of the CREB-family protein cAMP response-element modulator (CREM) was observed after CREB deletion. Viral overexpression of the activator isoform of CREM, CREM $\tau$, in the hippocampus also resulted in an accelerated response to antidepressants as well as increased hippocampal neurogenesis. This is the first demonstration of CREM $\tau$ within the brain playing a role in behavior and specifically in behavioral outcomes following antidepressant treatment. The current results suggest that activation of CREM $\tau$ may provide a means to accelerate the therapeutic efficacy of current antidepressant treatment.

\section{Introduction}

The mechanism by which the initial pharmacological action of antidepressants, increasing synaptic levels of monoamine neurotransmitters (Frazer, 1997), translates into their much slower onset of therapeutic efficacy is not fully understood (Wong and Licinio, 2001; Nestler et al., 2002). The transcription factor cAMP response element-binding protein (CREB) is thought to play a role in the long-term effects of antidepressants, as it regulates the expression of many genes that have been implicated in depression and antidepressant response (Nair and Vaidya, 2006; Tardito et al., 2006; Gass and Riva, 2007). The expression and activity of CREB are increased by chronic, but not acute, treatment with antidepressants in both rodent and postmortem human brain (Nibuya et al., 1996; Dowlatshahi et al., 1998; Malberg et al., 2000; Thome et al., 2000). However, some researchers have reported no

\section{Received April 18, 2013; revised July 11, 2013; accepted July 12, 2013.}

Author contributions: B.B.G. and J.A.B. designed research; B.B.G. and J.L.O. performed research; J.L. and K.H.K. contributed unpublished reagents/analytic tools; B.B.G., L.A.B., and J.L.O. analyzed data; B.B.G., L.A.B., and J.A.B. wrote the paper.

This work was supported by National Institute on Drug Abuse Grants R01-DA011649 (J.A.B.) and K99 DA033372 (L.A.B.), and National Institute for Mental Health Grant T32 MH017168 (B.B.G.).

The authors declare no financial conflicts of interest.

Correspondence should be addressed to Dr. Julie A. Blendy, Department of Pharmacology, University of Pennsylvania, TRL, 125 South 31st Street, Philadelphia, PA 19104. E-mail: blendy@mail.med.upenn.edu.

DOI:10.1523/JNEUROSCI.1669-13.2013

Copyright $\odot 2013$ the authors $\quad 0270-6474 / 13 / 3313673-13 \$ 15.00 / 0$ change or even decreases in CREB protein following antidepressant treatment (Blom et al., 2002; Laifenfeld et al., 2005), and it appears that the regulation of CREB by antidepressants differs depending on the brain region examined (Frechilla et al., 1998; Manier et al., 2002; Laifenfeld et al., 2005).

Numerous studies have examined the effects of changing the level of CREB expression in the brain on behavioral models of depression in rodents. $\mathrm{CREB}^{\alpha \Delta}$ mice, in which the $\alpha$ and $\Delta$ forms of CREB are constitutively deleted, show baseline increases in anxiety-like behavior, as well as antidepressant-like behavioral responses in the forced swim test (FST) and tail-suspension test (Conti et al., 2002; Gur et al., 2007; Mombereau et al., 2010). In the novelty-induced hypophagia procedure, in which chronic, but not acute, antidepressants are effective in wild-type animals, $\mathrm{CREB}^{\alpha \Delta}$ mice show an accelerated response to antidepressant treatment (Gur et al., 2007). CREB appears to differentially affect behavior depending on where it is expressed (Carlezon et al., 2005). For example, viral expression of a dominant-negative form of CREB, mCREB, has a prodepressant effect if it is localized to the hippocampus (Chen et al., 2001), or an antidepressant effect when localized to the nucleus accumbens or amygdala (Pliakas et al., 2001; Wallace et al., 2004).

One additional factor confounding the interpretation of results from both CREB knock-down and dominant-negative studies is the potential role of other CREB family transcription factors, such as the cyclic-AMP response element modulator 
(CREM) in producing phenotypes. Following deletion or reduced expression of CREB, CREM is upregulated (Hummler et al., 1994; Mantamadiotis et al., 2002) and may provide functional compensation for the loss of CREB, as phenotypes are often more severe after deletion of both CREB and CREM (Mantamadiotis et al., 2002; Lemberger et al., 2008). While a compensatory upregulation of CREM may be necessary for cell survival, particularly during development (Mantamadiotis et al., 2002), the transcriptional profile of CREM is not identical to CREB (Sasamori et al., 2008); therefore, upregulation of CREM may lead to a unique pattern of gene expression, and thus to behavior, not seen in wild-type mice. Furthermore, any compensatory change could lead to more dramatic changes during adulthood than during development as the number of transcriptional targets in adulthood is greater than those present during development (Kyrmizi et al., 2006; Gao et al., 2008).

To dissect the roles of CREB and CREM in regulating behavioral and cellular correlates of anxiety, depression, and antidepressant response, we deleted CREB specifically in the hippocampi of adult $C r e b^{\text {loxP/loxP }}$ mice using an adeno-associated virus (AAV) expressing Cre recombinase. As CREB deletion led to an upregulation of CREM expression, we overexpressed the CREM activator, CREM $\tau$, to determine whether this was sufficient to recapitulate the phenotype seen in CREB-deleted mice.

\section{Materials and Methods}

Animals. Mice containing the Creb1 gene with exon 10/11 flanked by loxP sites (Shin et al., 2013) were maintained on a C57BL/6 background. For all behavioral studies, Creb ${ }^{\text {loxP/loxP }}$ mice were injected with AAV-Cre virus in the hippocampus to cause specific deletion of CREB in this region. Control mice were $C r e b^{\operatorname{loxP} / l o x P}$ or $\mathrm{Creb}^{\text {loxP/+ }}$ animals injected with AAV-green fluorescent protein (GFP). Male and female mice were group housed with food and water available ad libitum (except as noted) and were maintained on a $12 \mathrm{~h}$ light/dark cycle (lights on at 7:00 A.M.) according to the University of Pennsylvania Animal Care and Use Committee. Mice weighed $20-40 \mathrm{~g}$ and were 3-5 months old at the time of behavioral testing.

Drugs. Desipramine (DMI) was dissolved in $0.9 \%$ saline immediately before use, and a volume of $10 \mathrm{ml} / \mathrm{kg}$ was injected intraperitoneally.

Adeno-associated virus production. The University of Pennsylvania Vector Core generated AAV constructs expressing Cre recombinase [AAV-Cre; AAV2/9.CMV.PI.Cre, titer $2.84 \times 10^{13}$ genome copies $(\mathrm{gc}) / \mathrm{ml}$ ], enhanced green fluorescent protein (AAV-GFP; AAV2/ 9.CMV.eGFP, titer $3.74 \times 10^{13} \mathrm{gc} / \mathrm{ml}$ ), or CREM $\tau$ (using a construct obtained from Green et al. (2006); AAV2/9.CMV.PI.mCREM, $9.81 \times$ $\left.10^{12} \mathrm{gc} / \mathrm{ml}\right)$. Each expression cassette contained AAV2 terminal repeats flanking the cytomegalovirus (CMV) promoter-PI-Cre recombinase, CMV promoter-enhanced GFP (EGFP), or CMV promoter-CREM $\tau$ sequences, packaged into AAV9. Vector purification was performed using a $\mathrm{CsCl}$ sedimentation method, and quantification of vector genome copies was performed by an RT-PCR method. AAVs were diluted in sterile PBS for microinjections.

Stereotaxic surgery and intrahippocampal microinjection. Surgery was performed on adult mice ( $6-8$ weeks). After anesthesia with isofluorane, mice were secured in a stereotaxic frame (Kopf). Holes were drilled bilaterally in the skull at the injection sites (four total). Stereotaxic coordinates used for intrahippocampal injections were as follows (from bregma): anterior-posterior -2.1 , lateral \pm 1.4 , dorsoventral -2.0 ; and anterior-posterior -2.9 , lateral \pm 3.0 , dorsoventral -3.8 . A 33-gauge needle attached to a $5 \mu$ l Hamilton syringe, mounted to the stereotaxic frame, and under control of a KDS310 Nano Pump (KD Scientific) was used to inject $0.5 \mu \mathrm{l}$ of $1 \times 10^{9} \mathrm{gc} / \mu \mathrm{lAAV}$ at each site. Injections occurred at a rate of $0.15 \mu \mathrm{l} / \mathrm{min}$, after which the needle was left in place for an additional $4 \mathrm{~min}$. After injections were completed, the skin was sutured and the animals were allowed to recover for $1 \mathrm{~h}$ on a heating pad before returning to the home cage. Mice remained in the home cage for
Table 1. Primers used for $q R T-P C R$ analysis

\begin{tabular}{lll}
\hline Gene & Forward primer & Reverse primer \\
\hline CREM & 5-CAGAGGAAGAAGGGACACCA-3' & 5'-TTGTATtGCCCCGTGCTAGT-3' \\
ICER & 5'-ATGGCTGTAACTGGAGATGAAACT-3' & 5'-GTAGGAGCTCGGATCTGGTAAGT-3' \\
TBP & 5'-CAGCAATCAACATCTCAGCAA-3' & 5'-GGGGTCATAGGAGTCATTGGT-3' \\
\hline
\end{tabular}

See Materials and Methods for further details.
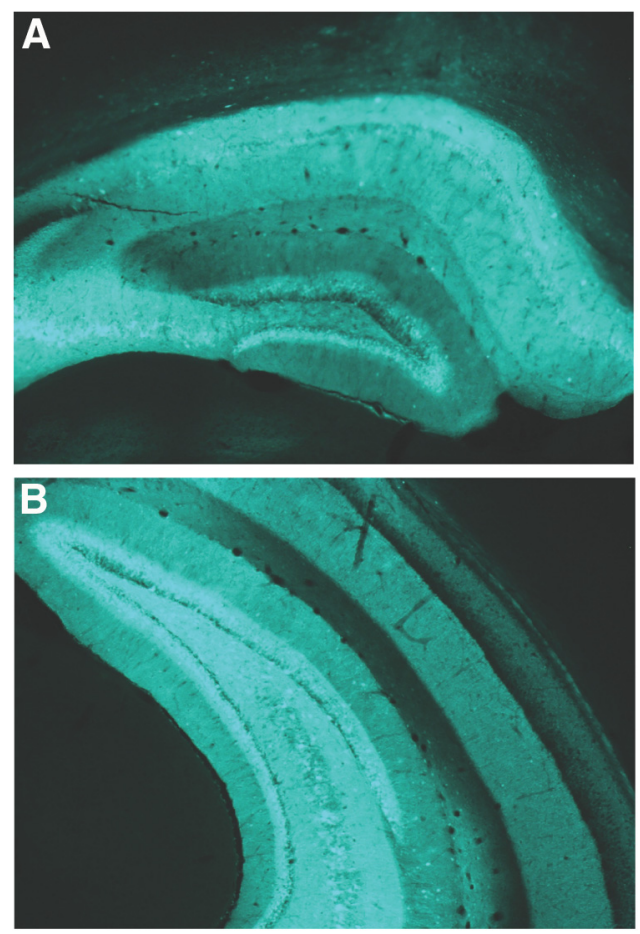

Figure 1. AAV-GFP spreads throughout, but not beyond hippocampus. $\boldsymbol{A}, \boldsymbol{B}$, Sections from dorsal $(\boldsymbol{A})$ and ventral $(\boldsymbol{B})$ hippocampus showing strong expression of EGFP throughout the hippocampus, 4 weeks after injection with AAV-GFP.

an additional 8 weeks before the start of behavioral testing, unless otherwise noted.

Behavioral studies. Behavioral experiments occurred between the hours of 8:00 A.M. and 3:00 P.M. Treatment conditions were assigned randomly, and animals were tested in counterbalanced order. All drug injections were given at least $1 \mathrm{~h}$ before the start of behavioral testing (unless otherwise noted), and animals were allowed to acclimate to testing rooms during this period.

Locomotor activity. Mice were placed into a clean home cage (one mouse/cage), resting within a photobeam frame (Med Associates). Locomotor activity was measured by beam-breaks and recorded by Med Associates software in $5 \mathrm{~min}$ bins for $1 \mathrm{~h}$. As changes in activity levels can affect other behaviors, measuring locomotor activity served as an important control.

FST. Mice were placed in plastic cylinders $(23 \mathrm{~cm}$ tall $\times 14 \mathrm{~cm}$ diameter) containing $15 \mathrm{~cm}$ of water $\left(22-24^{\circ} \mathrm{C}\right)$. The 6 min test was video recorded, and time spent in passive floating behavior ("immobility") versus active escape behaviors such as swimming and climbing was scored by a blinded observer. Mice received three injections of either saline or DMI $(15,15$, and $20 \mathrm{mg} / \mathrm{kg}) 24 \mathrm{~h}, 5 \mathrm{~h}$, and $30 \mathrm{~min}$ before the test. This dosing procedure was shown to be effective both in previous studies (Conti et al., 2002) as well as in pilot studies in this strain.

Elevated zero maze. Mice were given a 5 min exposure to the zero maze (Stoelting), which consisted of two open areas (wall height, 0.5 inch) and two closed areas (wall height, 12 inches), and was elevated 24 inches from the ground. Lighting in the maze was 15 lux, and mice began the 5 min exposure in one of the closed areas. The test was video recorded, and the Viewpoint Tracking System was used to quantify the amount of time 

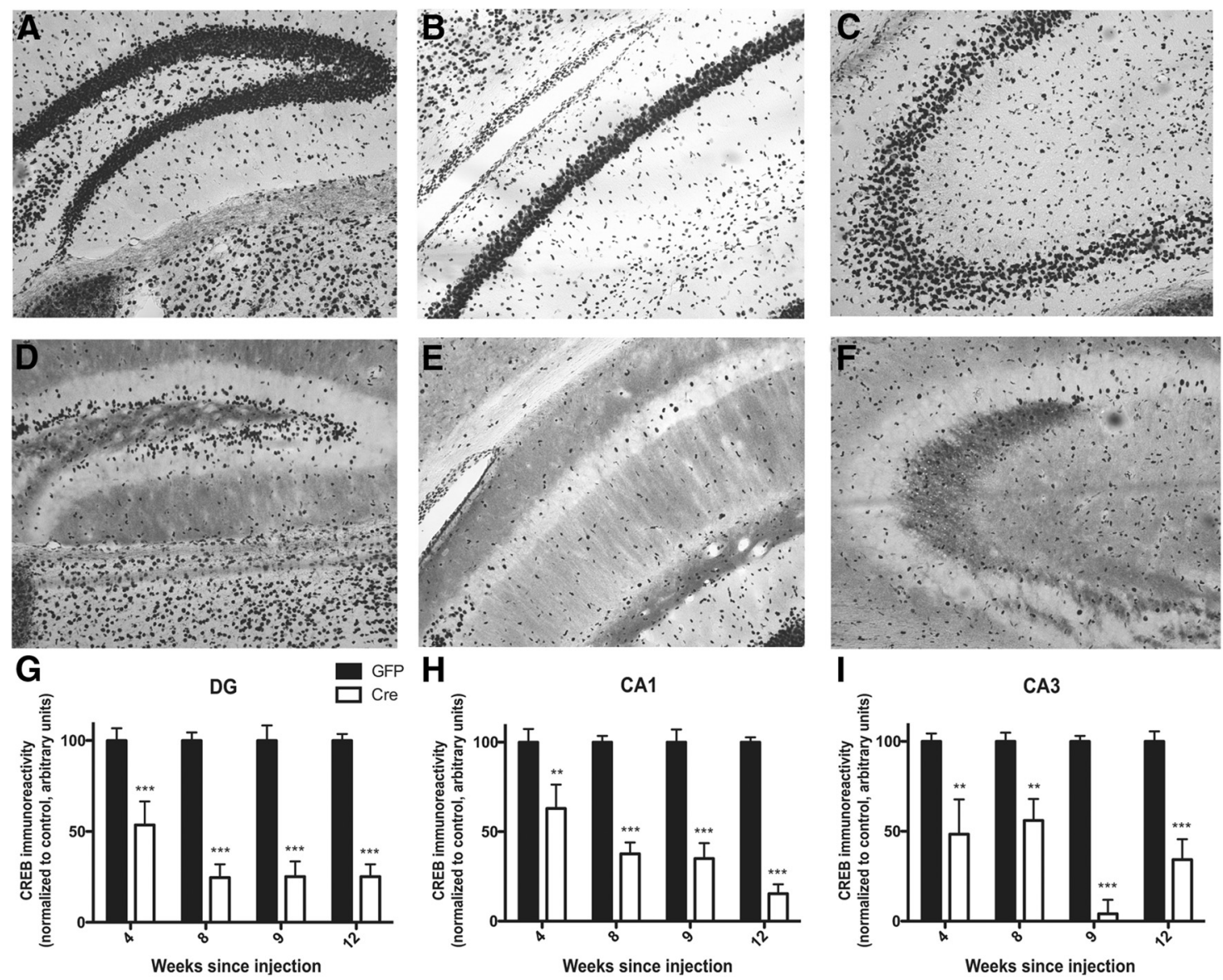

Figure 2. Intrahippocampal injection with AAV-Cre leads to robust and significant deletion of CREB in the hippocampus of Creb ${ }^{\text {loxP/loxP }}$ mice 8 weeks after injection. Hippocampal sections from the brains of $C$ reb ${ }^{\text {loxP } / 10 x P}$ mice $4,8,9$, and 12 weeks after intrahippocampal administration of AAV vectors were stained with an anti-CREB antibody. $A-F$, Representative photomicrographs of the dentate gyrus $(\boldsymbol{A}, \boldsymbol{D}), C \mathrm{CA}(\boldsymbol{B}, \boldsymbol{E})$, and $\mathrm{CA} 3(\boldsymbol{C}, \boldsymbol{F})$ subfields of the hippocampus. Extensive CREB staining is seen is seen in the AAV-GFP-injected animals $(\boldsymbol{A}-\boldsymbol{C})$, but is lacking in the AAV-Cre-injected animals $(\boldsymbol{D}-\boldsymbol{F}) . \mathbf{G}-\mathbf{I}$, Quantification of average staining in three hippocampal sections (approximate anterior-posterior coordinates: $-1.5,-2.5$, and -3.5 from bregma) showing significant reduction in CREB expression in DG $(\boldsymbol{G}), C A 1(\boldsymbol{H})$, and CA3 (I) subfields at all time points examined, with the greatest extent of deletion occurring by $8-9$ weeks after surgery ( 4 weeks: $n=7-8 ; 8$ weeks: $n=7-8 ; 9$ weeks: $n=8-10 ; 12$ weeks: $n=9-12) .{ }^{* *} p<0.01,{ }^{* * *} p<0.001$ versus equivalent AAV-GFP group. Error bars indicate SEM.

spent in the open areas, the number of entries into the open areas, and the distance traveled in each area.

Marble burying. The arena for marble burying consisted of a small plastic mouse cage $(26 \times 20 \times 14 \mathrm{~cm})$ covered in bedding to a depth of 5 $\mathrm{cm}$. Twenty marbles were equally distributed around the edge of the cage. Mice were placed in the cage (covered with a plastic lid), and left undisturbed for $15 \mathrm{~min}$. At the end of the testing period, mice were carefully removed from the cage and the number of marbles buried (covered three quarters or more in bedding) was counted by an experimenter blind to group.

Novelty-induced hypophagia. Mice were pair housed for at least 1 week before the start of and throughout the study. Training began 6 weeks after stereotaxic surgery, such that drug treatment and testing occurred at least eight weights postsurgery. During training and home-cage testing, plastic dividers were used to separate the two mice in each cage, and mice were allowed to acclimate to the divider and the testing room for $1 \mathrm{~h}$ before the beginning of the experiment. Training and home-cage testing consisted of a 15 min exposure to a highly palatable food (peanut butter chips; Nestle) in a small Petri dish (15 cm in diameter) in the home cage. Latency to approach and consume the food was measured. Mice were trained for $12-14 \mathrm{~d}$, or until their latencies had fallen to a consistent plateau.

In experiments with acute antidepressant treatment, testing began on the day following the last day of training, and mice received drug treatment in the morning and afternoon (9:00 A.M. and 5:00 P.M.) of each of the 3 testing days (home, novel, home), such that by the time of the novel test mice had received three administrations of drug. In the CREM overexpression study, mice received DMI injections beginning the day before the first home test, such that by the time of the novel test mice had received five drug administrations. In experiments with chronic antidepressant treatment, mice were given $21 \mathrm{~d}$ of twice-daily injections beginning after the last day of training. Following the 3 week treatment period, mice were tested in home, novel, and home environments, during which time they continued receiving twice-daily drug treatment at similar time points as in the acute study.

The novel environment test involved exposing mice to the food in an anxiogenic environment, which consisted of an empty standard cage, lacking bedding, which was placed in a white box with bright illumination (2150 lux) and with an added novel scent (Pine Sol or mint extract) applied to the cage. As in the home test, latency to consume food was measured by an experimenter blind to condition, with a maximum latency of $15 \mathrm{~min}$. Novel testing in both acute and chronic experiments occurred $1 \mathrm{~h}$ after separators were placed in the home cage and $1 \mathrm{~h}$ after mice received their last injection, parallel to the timing of home-cage testing.

Bromodeoxyuridine injection. Eight weeks following stereotaxic surgery, mice were administered a bromodeoxyuridine (BrdU) solution (Roche), by intraperitoneal injection, to label dividing cells. To evaluate cell proliferation, mice received a single bolus of $200 \mathrm{mg} / \mathrm{kg} \mathrm{BrdU}$ and were killed $24 \mathrm{~h}$ later. To evaluate the survival of newly generated cells, mice received four injections of $100 \mathrm{mg} / \mathrm{kg} \mathrm{BrdU}$ (one per day for $4 \mathrm{~d}$ ) and were killed 4 weeks after the last injection. 
Tissue collection for immunohistochemistry. Mice were anesthetized with sodium pentobarbital $(10 \mathrm{mg} / \mathrm{kg})$ and transcardially perfused with $40 \mathrm{ml}$ of PBS, followed by $30 \mathrm{ml}$ of $4 \%$ paraformaldehyde in PBS. Brains were removed and fixed in the same fixative overnight at $4^{\circ} \mathrm{C}$, after which they were transferred to a $30 \%$ sucrose solution (in PBS), which contained $0.1 \%$ sodium azide $\left(\mathrm{NaN}_{3}\right)$, for at least $48 \mathrm{~h}$ at $4^{\circ} \mathrm{C}$. Brains were frozen on dry ice, and $40 \mu \mathrm{m}$ sections were generated using a cryostat. Sections were placed in PBS with $0.1 \% \mathrm{NaN}_{3}$ and stored at $4^{\circ} \mathrm{C}$ until further processing. A series of every ninth section was used for immunohistochemistry.

BrdU immunohistochemistry. Immunohistochemistry was performed on slide-mounted sections encompassing the entire anterior-posterior axis of the hippocampus (10-12 sections per brain). Sections were boiled in heated citric acid $(0.1 \mathrm{M}, \mathrm{pH} 6.0)$ for $20 \mathrm{~min}$ for antigen retrieval. After washing in PBS, sections were treated with $0.1 \%$ trypsin solution with $0.1 \% \mathrm{CaCl}_{2}$ for $10 \mathrm{~min}$ to permeabilize cells. Following additional rinses, sections were treated for $30 \mathrm{~min}$ in $2 \mathrm{~N} \mathrm{HCl}$. Sections were rinsed again, after which they were incubated with mouse anti-BrdU (1:200; Becton Dickinson) with $0.5 \%$ Tween 20 overnight at room temperature. After rinsing, sections were incubated for $60 \mathrm{~min}$ in secondary antiserum (1: 200 biotinylated horse anti-mouse IgG; Vector Laboratories). Sections were rinsed, and incubated in avidin-biotin complex (Vector Laboratories) for $60 \mathrm{~min}$. After additional rinses, visualization was achieved with diaminobenzidine (DAB) tablets (Sigma). Sections were counterstained with $0.1 \%$ cresyl violet, dehydrated, and coverslipped.

Doublecortin immunohistochemistry. Free-floating sections were rinsed in PBS and incubated in a blocking solution of 3\% normal horse serum (Vector Laboratories) with $0.5 \%$ Tween plus $0.2 \%$ Triton in PBS for $1 \mathrm{~h}$. Sections were then incubated for $72 \mathrm{~h}$ at $4^{\circ} \mathrm{C}$ in goat-antidoublecortin (DCX; catalog \#8066; Santa Cruz Biotechnology), which was diluted 1:500 in blocking solution. After several rinses in PBS, sections were incubated in secondary antiserum (horse-anti-goat; Vector Laboratories), which was diluted 1:200 in blocking solution. Following additional rinses, sections were exposed to $0.75 \% \mathrm{H}_{2} \mathrm{O}_{2}$ in PBS for $20 \mathrm{~min}$ to block endogenous peroxidases. After several rinses, sections underwent a 60 min incubation in avidin-biotin complex (Elite ABC Kit; Vector Laboratories), which was diluted 1:200 in PBS. Staining was visualized with $0.04 \%$ DAB (Sigma) containing $0.01 \% \mathrm{H}_{2} \mathrm{O}_{2}$ and $0.06 \%$ nickel sulfate in Tris buffer for $10 \mathrm{~min}$, yielding a black reaction product. Sections were mounted on glass slides, dehydrated, and coverslipped.

CREB immunohistochemistry. Free-floating sections were incubated in $0.75 \% \mathrm{H}_{2} \mathrm{O}_{2}$ in PBS for $20 \mathrm{~min}$. After several rinses in PBS containing $0.3 \%$ Triton X-100 and $0.04 \%$ bovine serum albumin (PBS-Tx-BSA), sections were incubated overnight at $4^{\circ} \mathrm{C}$ in rabbit anti-CREB (catalog \#9197; Cell Signaling Technology), which was diluted 1:800 in PBS-TxBSA containing $0.1 \% \mathrm{NaN}_{3}$. After several rinses in PBS-Tx-BSA, sections were incubated in secondary antiserum (biotinylated donkey anti-rabbit; Jackson ImmunoResearch), which was diluted 1:200 in PBS-Tx-BSA for $90 \mathrm{~min}$. Sections were rinsed in PBS-Tx-BSA before incubation in avidin-biotin complex (Elite ABC Kit; Vector Laboratories) for 90 min. After additional rinses in PBS, sections were treated with $0.04 \%$ DAB (Sigma) containing $0.01 \% \mathrm{H}_{2} \mathrm{O}_{2}$ and $0.06 \%$ nickel sulfate in Tris buffer for $5 \mathrm{~min}$, yielding a black reaction product. The $\mathrm{DAB}$ reaction was terminated by additional rinses in PBS. For double labeling of DCX in addition to CREB, the procedure for DCX staining was performed as above, immediately following CREB visualization with DAB. DCX was visualized in this case with $0.04 \% \mathrm{DAB}$ containing $0.01 \% \mathrm{H}_{2} \mathrm{O}_{2}$ in $\mathrm{PB}$ for a brown reaction product. After processing, sections were mounted on glass slides, dehydrated, and coverslipped. Immunoreactivity was visualized using a Nikon Eclipse E600 microscope, and images were captured with a QImaging Retiga 1300 camera using Image-Pro Plus software (MediaCybernetics).

EGFP visualization. Untreated sections were wet mounted and visualized with a fluorescent microscope (Leica), and images were collected via an AxioCam HRc camera.

BrdU and DCX cell counting. BrdU cell counting was performed using a $100 \times$ oil-immersion lens on a Nikon Eclipse E600 microscope. All BrdU-labeled cells in the dentate gyrus granule cell layer (including cells within a distance of two cells from the granule cell layer) and hilus (all
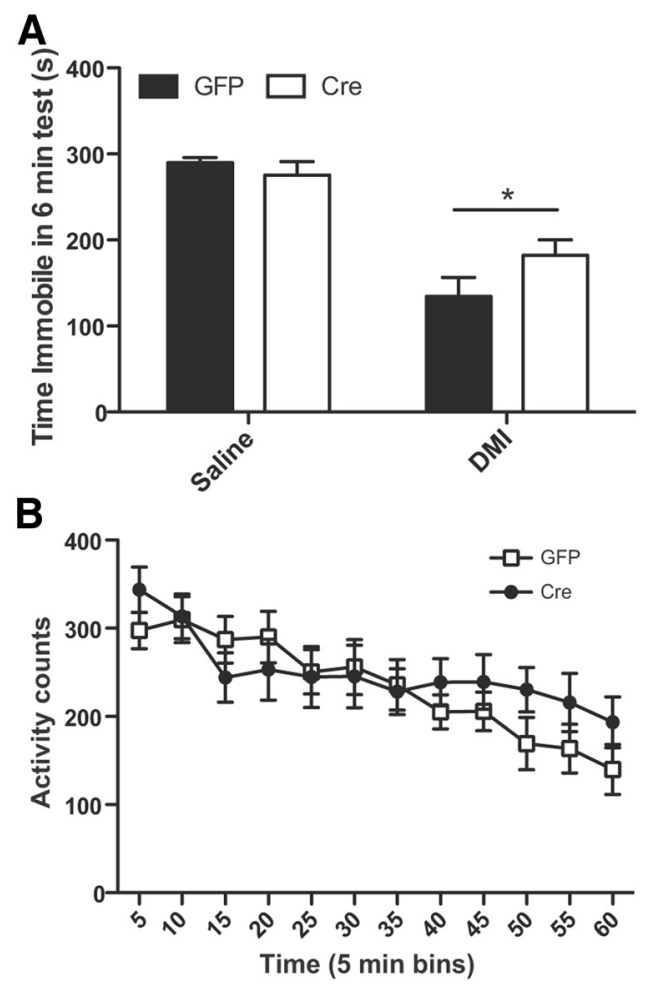

Figure 3. FST behavior and locomotor activity are not altered after hippocampal CREB deletion. $\boldsymbol{A}$, Immobility during a $6 \mathrm{~min}$ forced swim test is shown. Mice received a series of three injections of either saline or DMI over the $24 \mathrm{~h}$ before testing. DMI-treated mice of both AAVGFP- and AAV-Cre-injected mice showed a significant reduction in immobility $(n=7-8)$. There was no significant difference in immobility between AAV-GFP- and AAV-Cre-injected animals. ${ }^{*} p<0.05$ versus saline-treated animals. $\boldsymbol{B}$, Activity counts in a home-cage environment are shown. Activity counts were measured in $5 \mathrm{~min}$ bins over $60 \mathrm{~min}$. Although activity decreased significantly in both groups over time, there were no significant differences between AAV-GFPand AAV-Cre- injected animals ( $n=12$ ). Error bars indicate SEM.

other cells within the dentate gyrus) were counted in each section by an experimenter blinded to condition. The total number of BrdU-labeled cells was normalized to a harmonic mean of the number of hippocampal sections counted, as well as multiplied by 9 to result in the total number of BrdUlabeled cells per dentate gyrus. DCX-labeled cells were counted in a similar manner to BrdU-labeled cells, with the exception that all cells present in the granule cell layer were counted, and hilar cells were not quantified.

CREB immunohistochemical quantification. To assess the amount of CREB protein expressed throughout the hippocampus, three sections from each hippocampus were quantified, with the following anterior-posterior coordinates (from bregma): -1.5 (anterior to the anterior injection site); -2.5 (between the two injection sites); and -3.5 (posterior to the posterior injection site). For each of these sections, one picture each of the dentate gyrus, CA1 and CA3 subfields, taken at $10 \times$ magnification, were used. The regions of interest were outlined, and the integrated density of staining, normalized both to the area selected and the level of background staining, was measured. The average of the three sections was then calculated to produce one number for each of the three subfields. Levels of staining in the AAV-Cre-injected animals were normalized to AAV-GFP-injected animals to give a percentage reduction in CREB protein.

RNA extraction, $c D N A$ synthesis, and quantitative real-time PCR. Mice were killed by cervical dislocation directly from their home cages in the mouse colony, at least 1 week following any behavioral testing, for the evaluation of immediate early gene expression. Brains were rapidly removed, and whole hippocampi were hand dissected and frozen in liquid nitrogen. RNA was extracted from hippocampal tissue using TRIzol/ chloroform (Invitrogen) and the RNeasy Mini kit (Quiagen). cDNA was synthesized from RNA using an Oligo dT primer (Operon) and Superscript II reverse transcriptase (Invitrogen). Quantitative real-time PCR 
A
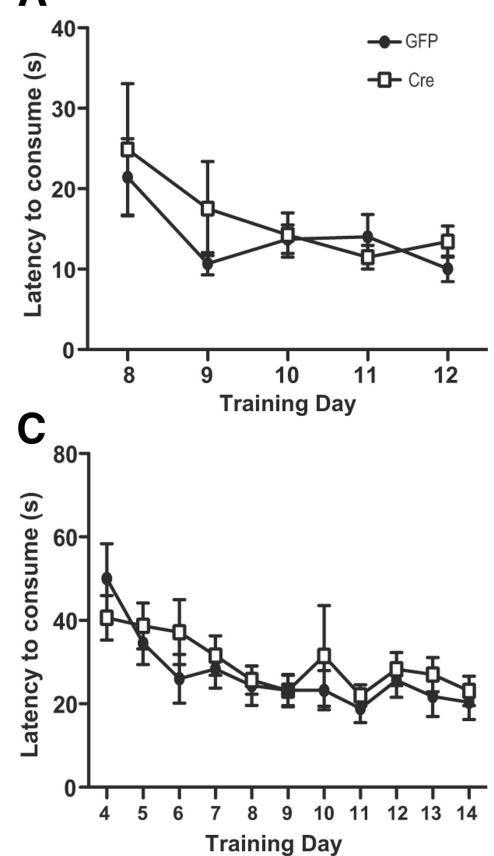

B

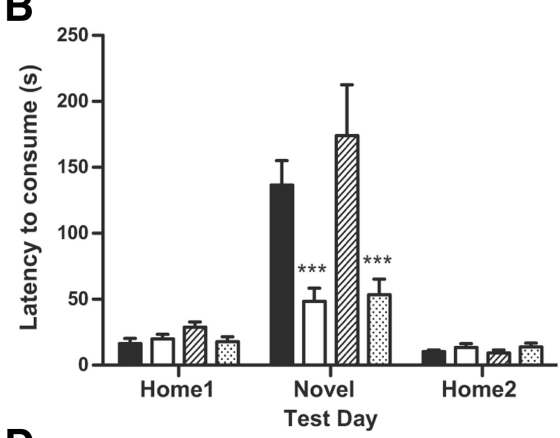

D

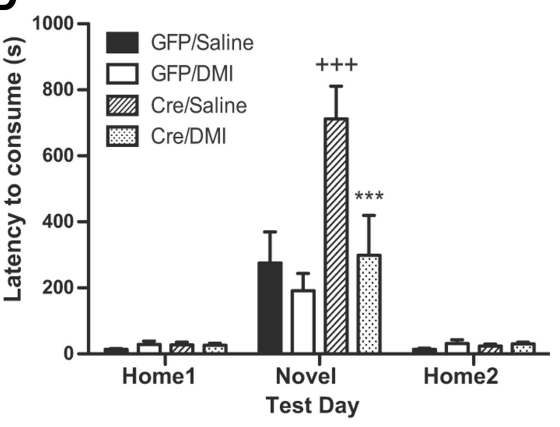

Figure 4. Hippocampal CREB deletion does not affect the response to chronic antidepressant treatment in the novelty-induced hypophagia procedure, but allows for response to acute antidepressant treatment in this procedure. $\boldsymbol{A}-\boldsymbol{D}$, Mice were trained and tested in the novelty-induced hypophagia procedure, with one cohort receiving 3 weeks of treatment with DMI (chronic, $\boldsymbol{A}$ and $\boldsymbol{B}$ ), and one cohort receiving only three administrations before testing (acute, $\boldsymbol{C}$ and $\boldsymbol{D}$ ). Latency to consume is shown. AAV-GFP-and AAV-Cre-injected mice did not show significant differences in training in either experiment $(\boldsymbol{A}, \boldsymbol{C} ; n=17-21)$. After chronic treatment, AAV-Cre-injected mice treated with saline showed a nonsignificant increase in latency to consume in the novel environment, but both AAV-GFP- and AAV-Cre-injected mice showed a significant reduction in latency to consume in the novel environment after 3 weeks of treatment with DMI $(\boldsymbol{B})$. There were no significant differences among the groups in home-cage behavior ( $n=6-10)$. After acute treatment, AAV-Cre-injected mice treated with saline showed a significant increase in latency to consume in the novel environment compared with their AAV-GFP-injected counterparts ( $\boldsymbol{D})$. Additionally, AAV-Cre-injected mice showed a significant reduction in latency after three administrations of DMI compared with their saline-treated counterparts, whereas AAV-GFP-injected animals did not show any change in response to DMI treatment. There were no significant differences among the groups in home-cage behavior $(n=8-10)$. ${ }^{* * *} p<0.001$ versus analogous saline-treated group; ${ }^{+++} p<0.001$ versus AAV-GFP-saline group. Error bars indicate SEM.

(qRT-PCR) was performed using SYBR-green master mix (Applied Biosystems) and $300 \mathrm{~nm}$ primers (final concentration), and was run on the Stratagene MX3000 using MXPro software. Cycling parameters were $95^{\circ} \mathrm{C}$ for $10 \mathrm{~min}$ followed by 40 cycles of $95^{\circ} \mathrm{C}(30 \mathrm{~s})$ and $60^{\circ} \mathrm{C}(1 \mathrm{~min})$, ending with a melting curve analysis to control for the amplification of a single gene product. All reactions were performed in triplicate, with the median cycle time used for analysis. TATA-box-binding protein (TBP) was used as a housekeeping gene against whose levels all experimental genes were normalized. Primer sequences can be found in Table 1 .

Protein extraction and Western blotting. Mice were taken directly from their home cages and killed by cervical dislocation $4 \mathrm{~h}$ following the second home test of the novelty-induced hypophagia procedure. Whole hippocampi and whole testes were hand dissected and frozen in liquid nitrogen. Tissue was homogenized in $200 \mu$ l of ice-cold extraction buffer containing PBS, 1 mм EGTA, 1 mм EDTA, 0.01\% SDS, and 1 mм PMSF. Protein concentrations were determined using a Bradford assay, with bovine serum albumin as the standard. Fifty micrograms of hippocampus or $25 \mu \mathrm{g}$ of testes protein was resolved on a $4-15 \%$ Tris- $\mathrm{HCl}$ gel using SDS-PAGE. Following electrophoresis, proteins were transferred to a nitrocellulose membrane. Membranes were incubated $1 \mathrm{~h}$ in blocking buffer (Licor) to block nonspecific binding. The blots were reacted with primary antibodies (anti-CREM 1:500, sc440, Santa Cruz Biotechnology; anti- $\beta$-tubulin 1:2000, catalog \#556321, BD Biosciences) overnight at $4^{\circ} \mathrm{C}$. After washing $3 \times 15 \mathrm{~min}$ in PBS with $0.5 \%$ Tween-20 (PBS-T), the blots were incubated in secondary antibody (goat anti-mouse IRDye 680 and goat anti-rabbit IRDye 800; LI-COR) in blocking buffer for $1 \mathrm{~h}$ at RT in dark boxes. Membranes were then washed $(3 \times 15 \mathrm{~min}$ in PBS-T) and dried overnight (also in the dark). Immunolabeling was detected and quantified using the Odyssey infrared Imaging System scanner and software (LI-COR). The CREM $\tau$ band was detected at $\sim 42 \mathrm{kDa}$, and was identified by strong expression in wild-type testes and absence in testes from $\mathrm{CREM}^{-1-}$ mice. The ratio of $\operatorname{CREM} \tau$ to $\beta$-tubulin fluorescence was calculated for each sample and analyzed across conditions.

Statistical analysis. For the elevated zero maze (EZM), marble burying, DCX immunohistochemistry, and gene expression studies (excluding c-fos), Student's unpaired $t$ test was used to assess statistical significance. For the forced swim test, c-fos expression, and CREB immunohistochemistry, ANOVA and Bonferroni's post hoc tests were used to assess significant differences between treatment groups. For locomotor activity, fear conditioning, and BrdU immunohistochemistry, repeatedmeasures ANOVA was performed with time bin (locomotor activity), testing period (preshock, postshock, and recall for fear conditioning), or brain region (granule cell layer or hilus for BrdU immunohistochemistry) as the repeated measure. For the novelty-induced hypophagia experiments, two-way, repeated-measures ANOVA was performed with day (home, novel, home) as the repeated measure. Bonferroni's post hoc tests were used to determine statistical differences in specific pairwise comparisons. Statistical significance was set at $p<0.05$.

\section{Results}

\section{Hippocampal injection of} adeno-associated virus expressing Cre recombinase in $\mathrm{Creb}^{\text {loxP/loxP }}$ mice leads to robust and specific decrease in CREB expression

To assess the role of CREB specifically in the adult hippocampus, we used a mouse in which deletion of CREB was inducible ( $C r e b^{\text {loxP/loxP }}$ mice). To limit the temporal and spatial extent of CREB deletion, we injected an AAV expressing Cre directly into this region in adult mice. An otherwise identical AAV expressing EGFP in place of Cre recombinase was used to determine the spatial extent of viral transduction and served as a control virus for all behavioral studies. Two weeks following surgery, GFP expression could be seen in the hippocampi of mice injected with AAV-GFP, and by 4 weeks there was robust expression throughout the anterior-posterior axis of the hippocampus, including both dorsal and ventral aspects (Fig. 1). Importantly, GFP was not observed outside of the hippocampus, suggesting that the virus had not spread to infect cells outside of this region. Additionally, we observed little damage at the injection site and no obvious neurodegeneration as a result of viral infection, based on gross visual inspection and as expected from previous reports (Kaspar et al., 2002; Ahmed et al., 2004).

The presence of virally expressed GFP in the hippocampus does not guarantee that Cre recombinase is expressed at adequate levels to effectively excise the floxed region of CREB. Therefore, to measure the amount of CREB protein in the hippocampus, we performed immunohistochemical labeling using an anti-CREB antibody at several time points after the viral injection (Fig. 2). In this and in subsequent experiments, $C r e b^{\text {loxP/loxP }}$ and $C r e b^{\text {loxP/+ }}$ 
animals injected with AAV-GFP were used as controls. At 4 weeks postinjection, levels of CREB protein were significantly reduced throughout the dorsal and ventral portions of each of the three subfields of the hippocampus examined [dentate gyrus (DG), CA1, and CA3], but still $\sim 50 \%$ of the levels found in controls (DG: effect of injection, $F_{(1,64)}=165, p<0.0001$; CA1: effect of injection, $F_{(1,60)}=149, p<0.0001$; effect of time, $F_{(3,60)}=3.75$, $p=0.016$; interaction, $F_{(3,60)}=3.751, p=0.016$; post hoc test: GFP vs Cre, $p<0.01$ for all time points; CA3: effect of injection, $F_{(1,61)}=97.7, p<0.0001$; effect of time, $F_{(3,61)}=3.017, p=$ 0.037 ; interaction, $F_{(3,61)}=3.017, p=0.037$; post hoc test: GFP vs Cre, $p<0.01$ for all time points; Fig. $2 G-I$ ). By 8 weeks postinjection, levels of CREB protein were reduced further in the DG and CA1 regions, and there was no consistent additional decrease in levels after 9 weeks postinjection (Fig. $2 G-I$ ). Based on these data, we conducted our behavioral studies in mice 8 weeks after they received surgery.

\section{Response to acute antidepressant treatment in the forced swim test is not altered by deletion of CREB in the hippocampus}

Antidepressant drugs cause decreased immobility in the forced swim test after acute administration (Lucki, 2001; Porsolt et al., 2001; Cryan et al., 2002). To determine whether hippocampal CREB is necessary for this response to antidepressants, we tested Creb ${ }^{\text {loxP/loxP }}$ mice injected with AAV-GFP and AAV-Cre in the hippocampus in this procedure. Mice injected with AAV-Cre did not show any difference in baseline levels of immobility in this procedure, and both groups of mice spent less time immobile if they had been acutely treated with the antidepressant DMI, regardless of viral injection (effect of drug, $F_{(1,26)}=53.2, p<$ 0.0001 ; Fig. $3 A$ ). Changes in levels of general locomotor activity can confound interpretation of results in the FST. There was no difference between animals injected with AAV-GFP and AAVCre in their levels of baseline activity in a home-cage environment over a $1 \mathrm{~h}$ period (effect of time, $F_{(11,242)}=11.50, p<$ 0.0001; Fig. 3B).

\section{Response to chronic antidepressant treatment in the novelty-induced hypophagia procedure is unaffected by loss of CREB in the hippocampus}

Because CREB is thought to play a role in long-term changes in gene expression and plasticity that might result from chronic antidepressant treatment, we assessed the role of hippocampal CREB in a procedure sensitive to treatment with chronic, but not acute, antidepressants: the novelty-induced hypophagia procedure (Merali et al., 2003; Dulawa and Hen, 2005). In wild-type animals, latency to consume a highly palatable food is increased in a novel environment. Chronic, but not acute, antidepressants reduce latency to consume in the novel environment. In this study, Creb $b^{\text {loxP/loxP }}$ mice behaved similarly, regardless of the viral injection they received. Viral injection did not affect training behavior (main effect of day, $F_{(4,36)}=3.341, p=0.011$; no significant effect of viral injection or virus $X$ day interaction; Fig. $4 A$ ). In the testing phase, all groups showed increased latency to consume in the novel environment, compared with the home cage, with the AAV-Cre-injected mice showing a nonsignificant trend toward higher latencies only after saline treatment, compared with their saline-treated AAV-GFP counterparts (effect of day, $F_{(2,58)}=35.44, p<0.0001$; effect of injection, $F_{(1,58)}=2.76$, $p=0.10$; Fig. $4 B$ ). Both AAV-GFP- and AAV-Cre-injected mice exhibited decreased latencies in the novel environment after 3 weeks of treatment with DMI (effect of drug, $F_{(1,58)}=27.18, p<$
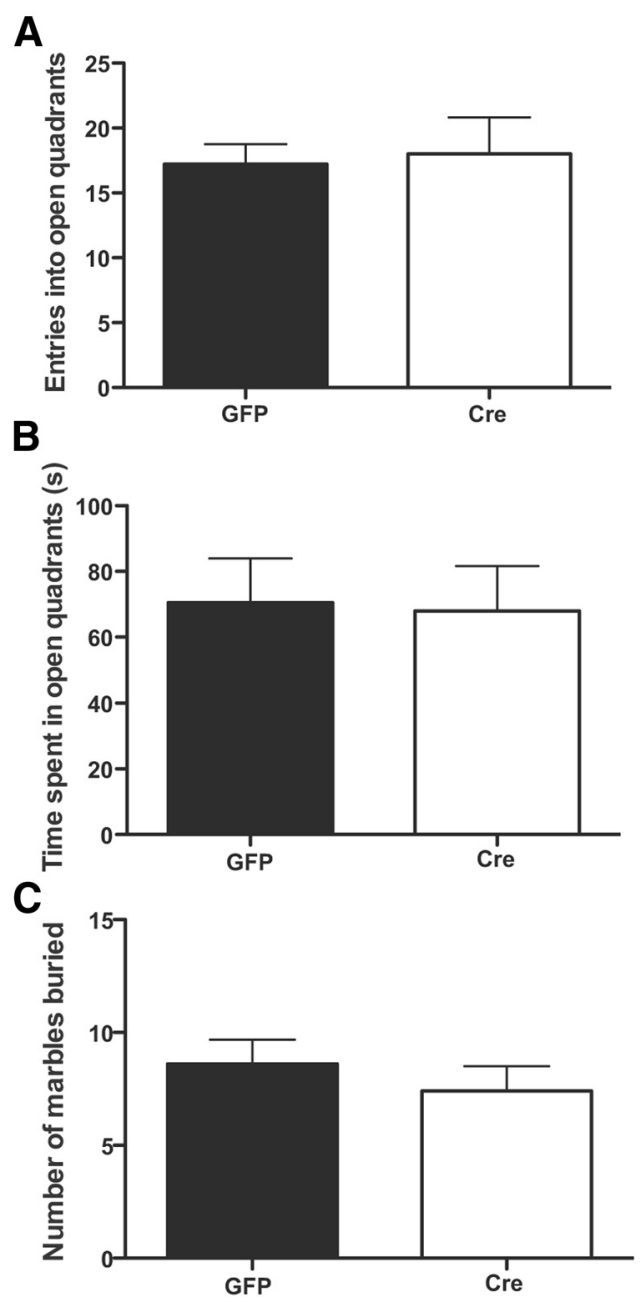

Figure 5. Hippocampal CREB deletion does not alter anxiety behavior in the EZM or marble burying. $\boldsymbol{A}, \boldsymbol{B}$, Mice were placed in the EZM for $5 \mathrm{~min}$. Mice injected with the Cre-expressing virus did not differ from those injected with GFP-injected virus in number of entries into open quadrants $(\boldsymbol{A})$ or time spent in open quadrants $(\boldsymbol{B} ; n=9)$. $\boldsymbol{C}$, Anxiety behavior was also assessed in a marble-burying procedure. There was no significant difference in the number of marbles buried between AAV-GFP-injected and AAV-Cre-injected mice $(n=10)$. Error bars indicate SEM.

0.0001 ; interaction, $F_{(2,58)}=11.37, p<0.0001$; Fig. $\left.4 B\right)$. Thus, response to chronic treatment with $\mathrm{DMI}$ in this procedure remains intact after deletion of CREB in the hippocampus.

\section{Hippocampal CREB deletion accelerates antidepressant treatment in the novelty-induced hypophagia}

Mice with a constitutive deletion of $\operatorname{CREB}\left(\mathrm{CREB}^{\alpha \Delta}\right)$ show a reduction in latency to consume in the novel environment of the novelty-induced hypophagia procedure after only three antidepressant administrations (Gur et al., 2007). Therefore, we examined whether the more specific loss of CREB in the hippocampus would recapitulate this phenotype. $C r e b^{\text {loxP/loxP }}$ mice were tested in the novelty-induced hypophagia procedure, 8 weeks after intrahippocampal injection with AAV-GFP or AAV-Cre. As with the chronic experiment, there were no differences in training between mice injected with either virus (effect of day, $F_{(10,340)}=$ 5.268, $p<0.0001$; Fig. 4C). All groups exhibited increased latency to consume in the novel environment, when compared with the home cage, with saline-treated AAV-Cre-injected animals having significantly higher latencies in the novel environment compared with their saline-treated AAV-GFP counterparts (effect of day, 
A
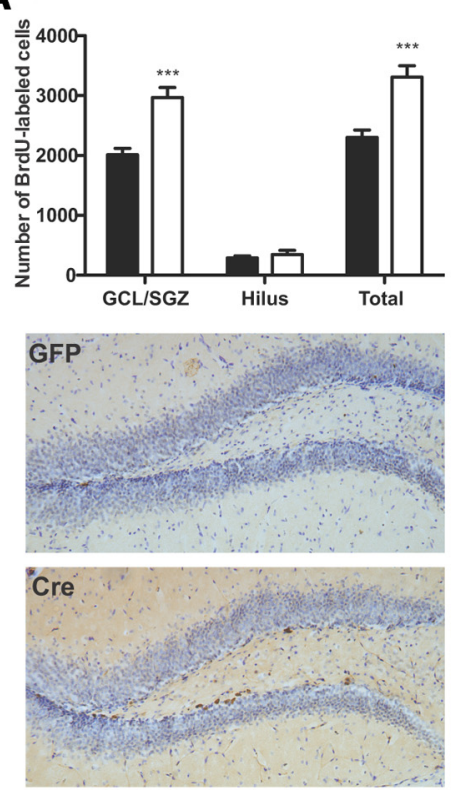

B
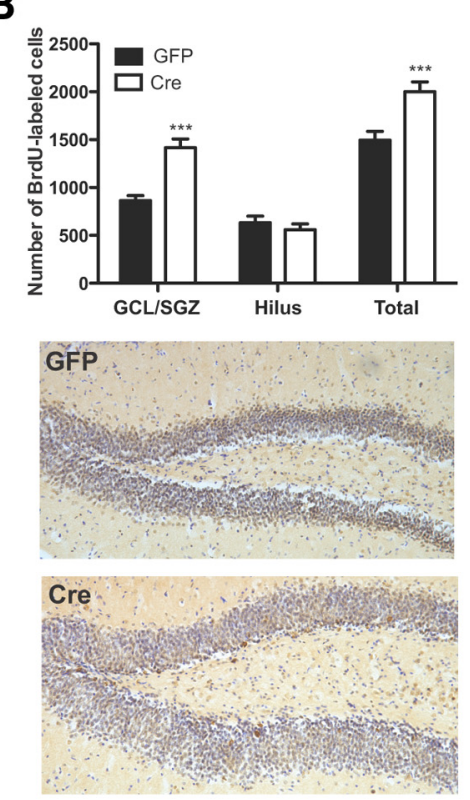

C
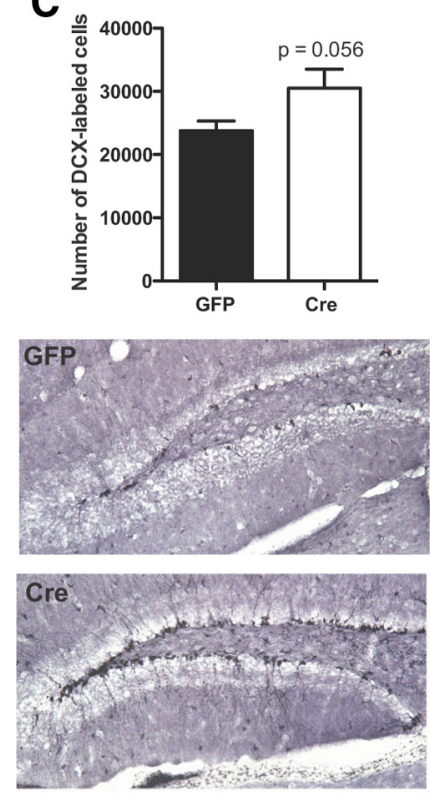
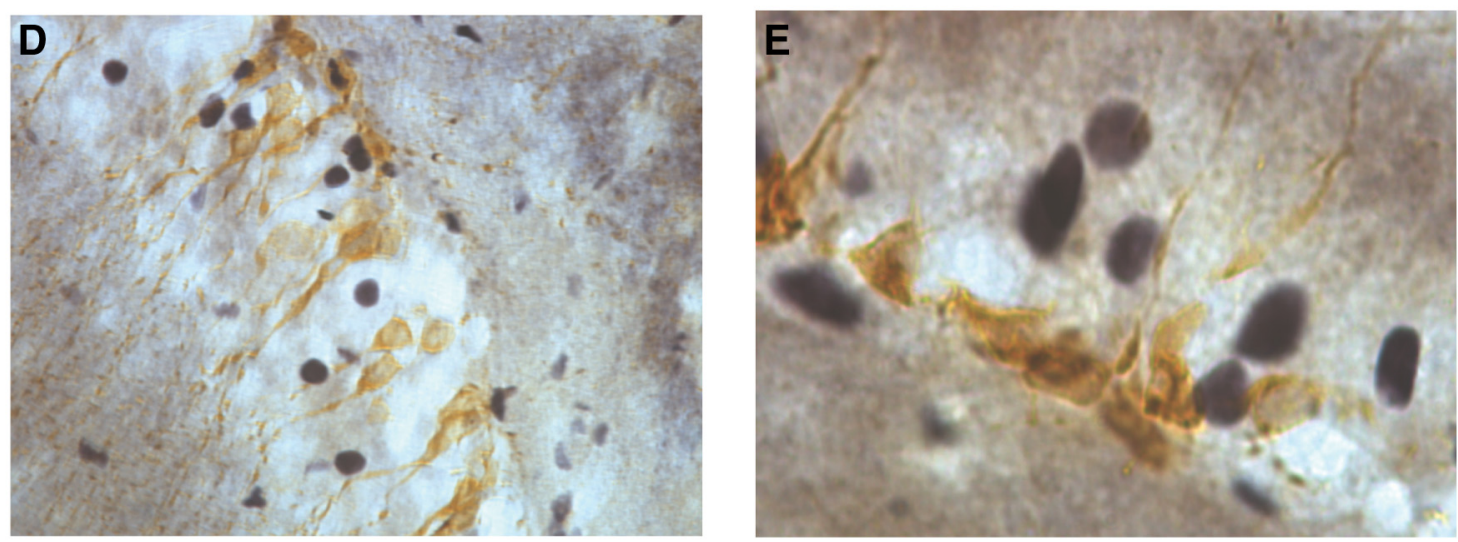

Figure 6. Deletion of CREB in the hippocampus causes a significant increase in hippocampal neurogenesis. $A, B$, Quantification of the number of BrdU-labeled cells in the dentate gyrus $G C L / S G Z$ and hilus are shown. Example images of the DG from AAV-GFP-injected (middle) and AAV-Cre-injected animals (bottom) after staining with anti-BrdU antibody (brown) and counterstaining with cresyl violet (purple) are shown. $A$, Mice were killed $24 \mathrm{~h}$ following a single injection of BrdU. There was a significant increase in BrdU-labeled cells in the GCL/SGZ, but not in the hilus, of AAV-Cre-injected mice, compared with AAV-GFP-injected mice, indicating an increase in cell proliferation $(n=14-15)$. $\boldsymbol{B}$, Mice were killed 4 weeks following a series of four BrdU injections. AAV-Cre-injected mice showed significantly higher levels of BrdU-injected cells in the GCL/SGZ, but not the hilus, compared with AAV-GFP-injected controls, suggesting a sustained increase in the number of newly generated (surviving) cells $(n=7-10)$. ${ }^{* * *} p<0.001$ versus AAV-GFP-injected controls. $C$, The number of DCX-labeled cells in the dentate gyrus granule cell layer of mice killed 12 weeks after hippocampal microinjection is shown (top). Deletion of CREB in the hippocampus caused a sizable and nearly significant increase in the number of $D C X$-labeled cells, compared with AAV-GFP-injected controls $(n=8-9)$. Example images of the DG from AAV-GFP-injected (middle) and AAV-Cre-injected (bottom) animals stained with antibody against doublecortin are shown. Error bars indicate SEM. D, E, Most immature neurons in AAV-Cre-injected dentate gyrus do not express CREB. Example pictures of the dentate gyrus from an AAV-Cre-injected animal after staining with antibodies against doublecortin (brown) and CREB (black) at $40 \times(\boldsymbol{D})$ and $100 \times(\boldsymbol{E})$ magnification.

$F_{(2,64)}=56.6, p<0.0001 ;$ effect of injection, $F_{(1,64)}=8.3, p=$ 0.006 ; effect of drug, $F_{(1,64)}=5.4, p=0.02$; interaction, $F_{(2,64)}=$ $2.968, p=0.05$; post hoc test: AAV-GFP-saline vs AAV-Cresaline, $p=0.0061$; Fig. $4 D$ ). Just three doses of DMI significantly reduced latencies in the novel environment of AAV-Cre-injected mice, compared with their saline-treated counterparts (post hoc test: AAV-Cre-DMI vs AAV-Cre-saline, $p=0.02$ ). AAV-GFPinjected animals had similar latencies regardless of drug treatment. Thus, loss of CREB in the hippocampus allows for a response to short-term antidepressant treatment in the noveltyinduced hypophagia procedure. No body weight differences were seen between AAV-Cre- or AAV-GFP-injected mice, and animals were balanced based upon body weight when assigned to drug treatment groups $(\mathrm{GFP} / \mathrm{saline}=28.00 \pm 1.9 ; \mathrm{GFP} / \mathrm{DMI}=$ $29.38 \pm 2.5 \mathrm{~g} ;$ Cre/saline $=28.50 \pm 1.6 ; \mathrm{Cre} / \mathrm{DMI}=27.13 \pm 1.7)$.

\section{Hippocampal deletion of CREB does not affect behavior in two tests of anxiety}

CREB has been implicated in anxiety behavior (Barrot et al., 2002; Graves et al., 2002; Wallace et al., 2004), and in the noveltyinduced hypophagia procedure, mice with hippocampal CREB deletion showed an increase in latency to consume in the novel environment, suggestive of increased anxiety-like behavior (Fig. $4 B, D)$. Therefore, we tested $C r e b^{\text {loxPlloxP }}$ mice in two other tests of anxiety-like behavior, 8 weeks after injection with AAV-GFP or AAV-Cre in the hippocampus. In the EZM, AAV-Cre-injected mice did not show differences in the level of anxiety-like behavior, as indicated by a similar number of entries into open quadrants (Fig. 5A) as well as a similar amount of time spent in open quadrants (entries: $t_{(16)}=0.2414, p=0.81$; time: $t_{(18)}=0.0515$, $p=0.95$; Fig. $5 B$ ). In the marble-burying procedure, another 
measure of anxiety-like behavior, AAV-GFP and AAV-Cre mice again exhibited similar levels of anxiety-like behavior, with no significant difference between the groups in the number of marbles buried $\left(t_{(18)}=0.7732, p=0.44\right.$; Fig. $\left.5 C\right)$.

\section{Hippocampal neurogenesis is increased after deletion of CREB}

In addition to a response to acute treatment with antidepressants in the novelty-induced hypophagia procedure, CREB-deficient $\mathrm{CREB}^{\alpha \Delta}$ mice show increased rates of hippocampal neurogenesis (Gur et al., 2007). Indeed, the antidepressant-induced reduction in latency to consume in the novel environment of the noveltyinduced hypophagia procedure may require concomitant increases in hippocampal neurogenesis (Santarelli et al., 2003). To assess levels of hippocampal neurogenesis in mice after hippocampal CREB deletion, we administered BrdU, a marker of cell division, to $C r e b^{\text {loxP/loxP }}$ mice 8 weeks after they were given hippocampal injections of either AAV-GFP or AAV-Cre. The number of BrdU-labeled cells in the DG was determined in mice killed either $24 \mathrm{~h}$ or 4 weeks after BrdU administration. As shown in Figure $6 A$, the DG of AAV-Cre-injected mice contained greater numbers of BrdU-labeled cells than those from mice injected with AAV-GFP and killed $24 \mathrm{~h}$ after treatment with BrdU, indicating higher levels of cell proliferation in this group (effect of injection, $F_{(1,54)}=52.86, p<0.0001$; effect of area, $F_{(2,54)}=$ $221.2, p<0.0001$; interaction, $\left.F_{(2,54)}=8.614, p=0.0006\right)$. Four weeks after BrdU administration, AAV-Cre-injected mice retained a significant increase in BrdU-labeled cells compared with corresponding AAV-GFP-injected mice, suggesting that larger numbers of newly produced cells had survived in this group (effect of injection, $F_{(1,30)}=11.29, p=0.0043$; effect of area, $F_{(2,30)}=171.1, p<0.0001$, interaction, $F_{(2,30)}=15.54, p<$ 0.0001 ; Fig. $6 B$ ). The significant increase in the total number of BrdU-labeled cells in AAV-Cre-injected mice was driven by a significant increase in labeled cells in the granule cell layer/subgranular zone (GCL/SGZ) of the dentate gyrus, whereas the numbers of labeled cells in the hilus were similar between the groups (post hoc test: AAV-GFP vs AAV-Cre, $p<0.001$ for GCL/SGZ, $p>0.05$ for hilus, $p<0.001$ for total at both time points).

In wild-type animals, the vast majority of newly generated cells in the DG differentiate into neurons. To determine whether this was true of the increased number of newly generated cells in mice with CREB deletion in the hippocampus, we conducted immunohistochemistry with an antibody recognizing DCX, a marker of immature neurons. Twelve weeks postsurgery, AAVCre-injected mice showed an increase in DCX-positive cells similar in magnitude to the increase in BrdU-positive cells, though the difference between the AAV-GFP- and AAV-Cre-injected groups did not reach statistical significance $\left(t_{(15)}=2.067, p=\right.$ 0.0565; Fig. 6C).

Because the serotype of AAV we used, AAV2/9, is known to infect neurons more efficiently than glial cells (Cearley and Wolfe, 2006; Klein et al., 2008), and because neural progenitor cells (NPCs) are glia like (Seri et al., 2001), we investigated whether CREB expression remained in newly created neurons. We labeled hippocampal sections taken from mice killed 12 weeks after microinjection with AAV-Cre in the hippocampus with antibodies against both DCX and CREB (Fig. 6E,F). Sections from AAV-GFP-injected animals, in which CREB is not deleted, show CREB staining in the dentate gyrus too dense to resolve individual cells. In mice injected with AAV-Cre, we found large numbers of cells labeled for DCX (914 \pm 346$)$, and CREB $(1592 \pm 841)$, but few cells labeled with both antibodies $(28 \pm$
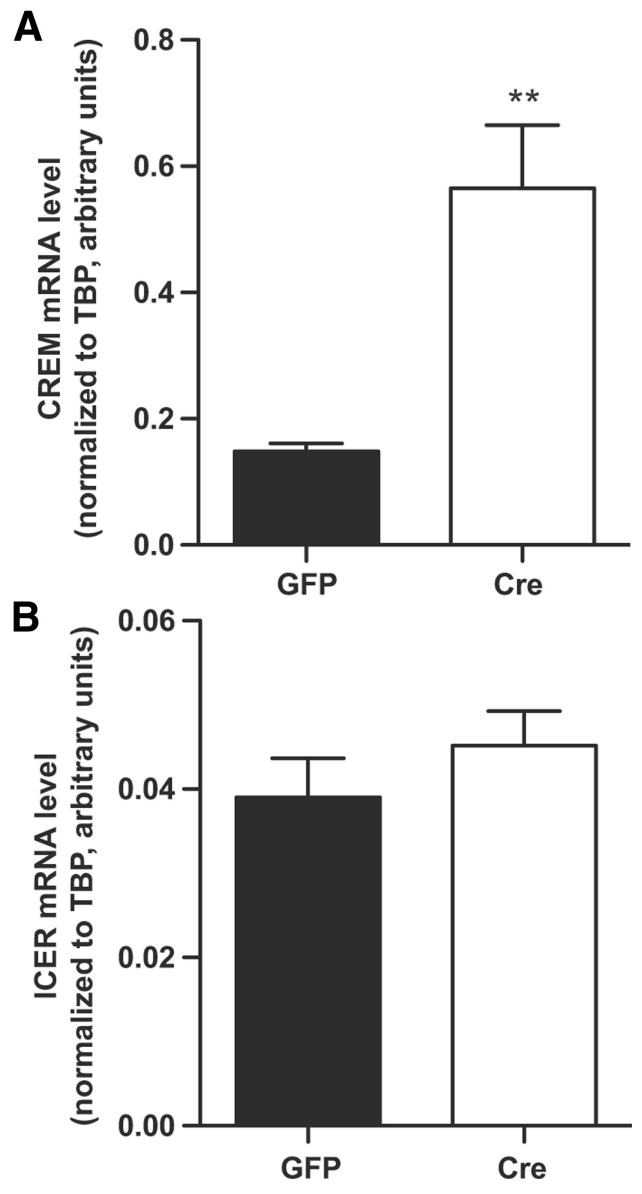

Figure 7. $\quad \boldsymbol{A}, \boldsymbol{B}$, Deletion of $(R E B$ in the hippocampus leads to a robust increase in the expression of CREM $(\boldsymbol{A})$, but not of ICER $(\boldsymbol{B})$ in the hippocampus ( $n=7-8)$. Levels of CREM and ICER mRNA in the hippocampus, as determined by RT-PCR, were normalized to the housekeeping gene TBP. ${ }^{* *} p<0.01$ versus AAV-GFP-injected controls. Error bars indicate SEM.

16). Thus, a very small percentage of DCX-expressing cells also expressed CREB (2.9\%), suggesting that NPCs are being infected efficiently.

\section{Deletion of CREB in the hippocampus leads to selective upregulation of CREM, a related CRE-binding transcription factor}

In other models in which CREB expression is reduced, upregulation of the CREB family protein CREM has been observed and is thought to affect the severity of phenotypes resulting from reduction of CREB (Hummler et al., 1994; Mantamadiotis et al., 2002). Using qRT-PCR, we measured levels of CREM mRNA in the hippocampi of $C r e b^{\text {loxP/loxP }}$ mice 8 weeks after hippocampal injection with either AAV-GFP or AAV-Cre. As in other models of CREB reduction, we saw a robust and significant increase in CREM mRNA in the hippocampi of AAV-Cre-injected mice, compared with AAV-GFP-injected controls $\left(t_{(13)}=3.858, p=\right.$ 0.002; Fig. 7A). There are many isoforms of CREM, including those acting as transcriptional activators and repressors. The above experiment used primers designed to amplify most isoforms, including the main activator form $\operatorname{CREM} \tau$, which is normally expressed only at low levels in brain (Foulkes et al., 1992). One isoform not amplified by these primers is the main repressor form of CREM, inducible cAMP early repressor (ICER). Using primers specifically designed against ICER, we saw no change in 
A

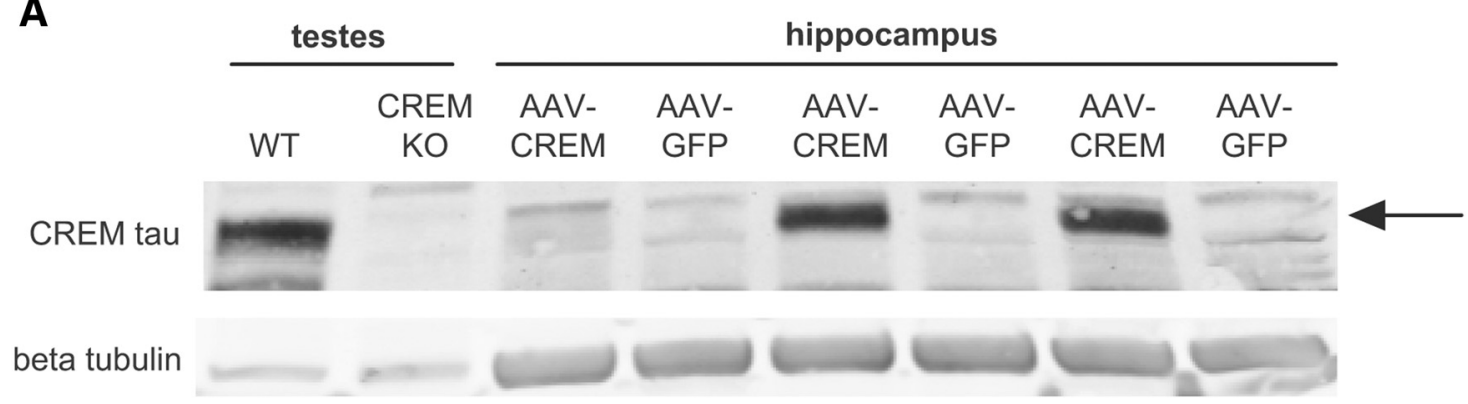

B

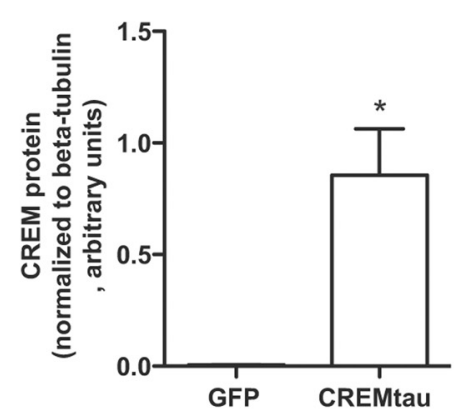

C

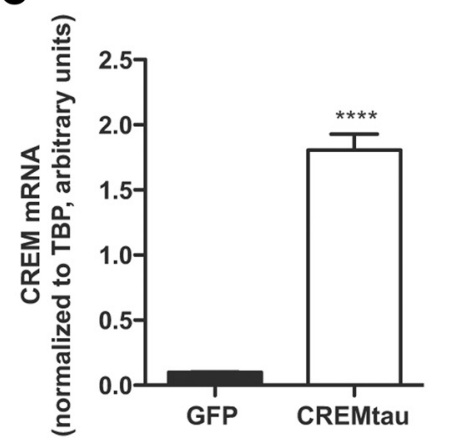

D

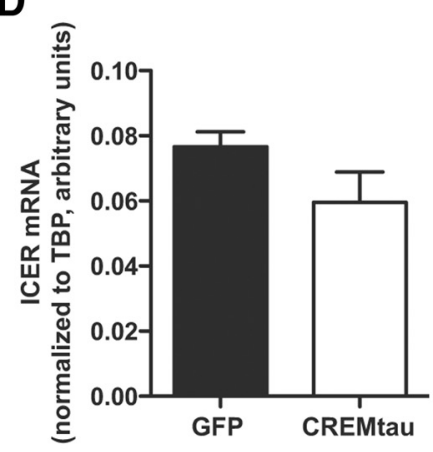

Figure 8. CREM $\tau$ overexpression in the hippocampus. $A$, Representative Western blot showing increased CREM protein in hippocampal tissue following injection with AAV-CREM $\tau$. $B$, Quantification of Western blot showing robust and significant increase in CREM protein in the hippocampus following injection with AAV-CREM $\tau$, as normalized to $\beta$-tubulin ( $n=6)$. $C, D, A n$ increase in CREM mRNA was also observed in the hippocampi of mice injected with AAV-CREM $\tau(\boldsymbol{C} ; n=6-7)$. Levels of ICER mRNA were unchanged by viral injection $(\boldsymbol{D} ; n=6-7)$. ${ }^{*} p<0.01$ versus AAV-GFP-injected controls; ${ }^{* * *} p<0.0001$ versus AAV-GFP-injected controls. Error bars indicate SEM.

mRNA levels in $C r e b^{\text {loxP/loxP }}$ mice, regardless of the viral injection they received $\left(t_{(13)}=0.9947, p=0.33\right.$; Fig. $\left.7 B\right)$.

\section{Overexpression of CREM in the hippocampus is sufficient to recapitulate the phenotype of hippocampal CREB deletion in the novelty-induced hypophagia procedure}

We hypothesized that the increased expression of CREM resulting from deletion of CREB in the hippocampus might be driving the behavioral phenotype we observed. To test this hypothesis, we overexpressed the activator isoform of CREM, CREM $\tau$, specifically in the hippocampus using an AAV vector identical to the one used to overexpress Cre recombinase (AAV-CREM $\tau$ ). Hippocampal injection of AAV-CREM $\tau$ caused a robust and significant increase in CREM expression in the hippocampus, as assessed by Western blotting $\left(t_{(10)}=4.103, p=0.0021\right.$; Fig. $8 A, B)$. Consistent with our Western blotting data, we saw a robust and significant increase in total CREM mRNA in the hippocampi of AAV-CREM $\tau$-injected animals, compared with AAV-GFP-injected controls $\left(t_{(10)}=13.96, p<0.0001\right.$; Fig. $\left.8 C\right)$. This increase in CREM expression did not include an increase in the expression of the main CREM repressor isoform, ICER, for which mRNA levels were equivalent regardless of viral injection (Fig. 8D).

To assess whether the higher levels of CREM $\tau$ in the hippocampus induced by viral overexpression would recapitulate the behavioral phenotype of CREB deletion in this region, we assessed the response to acute antidepressants in the noveltyinduced hypophagia procedure in these animals. Animals were trained in the novelty-induced hypophagia procedure 2 weeks following viral injection. Expression of CREM did not affect training (Fig. 9A). In the testing phase, all mice exhibited higher latencies to consume in the novel environment compared with the home cage, and saline-treated AAV-CREM $\tau$-injected mice showed a significantly larger increase in latency to consume in the novel environment than their AAV-GFP-injected counterparts (effect of day, $F_{(2,31)}=47.642, p<0.0001$; effect of drug, $F_{(2,31)}=$ 13.907, $p<0.0001$; interaction, $F_{(2,31)}=3.597, p=0.033$; post hoc test on novel day: AAV-GFP-saline vs AAV-CREM $\tau$-saline, $p<0.001$; Fig. 9B). Acute treatment with DMI significantly reduced latency to consume in the novel environment in AAVCREM $\tau$-injected mice (post hoc test: AAV-CREM $\tau$-saline vs AAV-CREM $\tau$-DMI, $p<0.0001$ ), whereas it had no effect in AAV-GFP-injected animals. No weight differences were seen between the AAV-GFP-injected controls and the AAV-CREM $\tau$ injected mice (GFP, $24.88 \pm 0.81 \mathrm{~g}$; $\mathrm{CREM} \tau, 25.02 \pm 0.93 \mathrm{~g}$ ).

\section{Overexpression of CREM in the hippocampus is sufficient to} increase hippocampal neurogenesis

In CREB-deficient mice, both the $\mathrm{CREB}^{\alpha \Delta}$ (Gur et al., 2007) and $\mathrm{Creb}^{\text {loxP/loxP }}$ animals (Figs. 4, 6), the accelerated response to antidepressants in the novelty-induced hypophagia procedure was accompanied by an increase in hippocampal neurogenesis. Therefore, we examined whether this correlation was also present in mice overexpressing CREM $\tau$ in the hippocampus. Four weeks following hippocampal injection with either AAV-CREM $\tau$ or AAV-GFP, mice were injected with BrdU and killed $24 \mathrm{~h}$ later. When BrdU-labeled cells were counted in the dentate gyrus, CREM $\tau$-overexpressing animals showed significantly higher numbers of labeled cells than their GFP-expressing counterparts, within the granule cell layer (effect of virus, $F_{(1,42)}=6.15, p=$ 0.019 ; effect of area, $F_{(2,42)}=66.15, p<0.0001$; interaction, $F_{(2,42)}=1.57, p=0.0134$; post hoc test: AAV-GFP vs AAVCREM $\tau, p<0.05$ ) and overall ( $p o s t$ hoc test: AAV-GFP vs AAV$\operatorname{CREM} \tau, p<0.01$; Fig. 10). There was no difference in the number of labeled cells found in the hilus. 

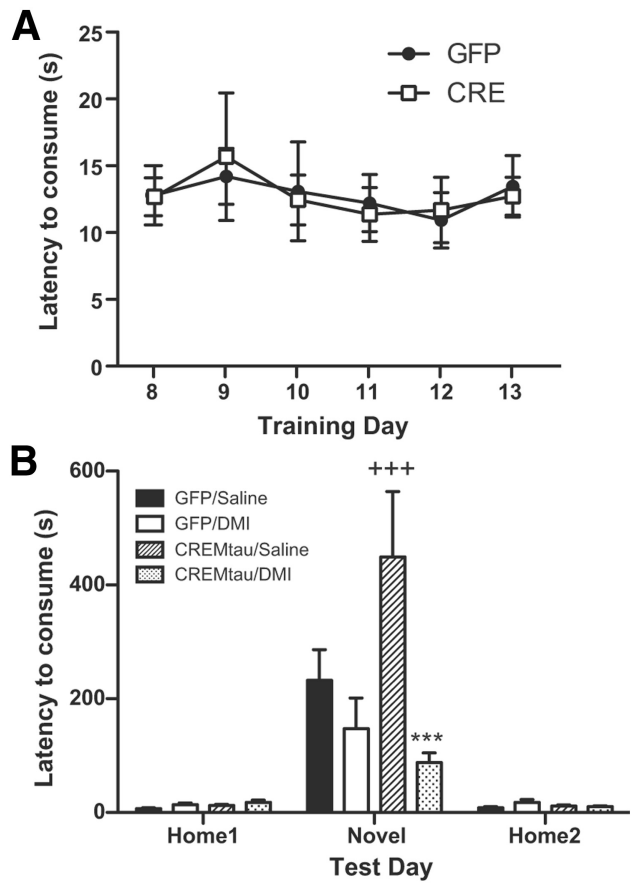

Figure 9. Overexpression of CREM $\tau$ in the hippocampus is sufficient to produce an accelerated response to antidepressant treatment in the novelty-induced hypophagia procedure. Mice were trained and tested in the novelty-induced hypophagia procedure beginning 2 weeks after viral injection with either AAV-CREM $\tau$ or AAV-GFP. Latency to consume is shown. A, AAV-GFPand AAV-CREM $\tau$-injected mice did not show significant differences in trainingc $(n=24-25)$. $B, A A V-C R E M \tau$-injected mice treated with saline showed a significant increase in latency to consume in the novel environment compared with their AAV-GFP-injected counterparts. Additionally, AAV-CREM $\tau$-injected mice showed a significant reduction in latency after acute treatment DMI, compared with their saline-treated counterparts, whereas AAV-GFP-injected animals did not show any change in response to DMI treatment. There were no significant differences among the groups in home-cage behavior $(n=9-12)$. ${ }^{* *} p<0.0001$ versus analogous saline-treated group; ${ }^{+++} p<0.001$ versus AAV-GFP-saline group. Error bars indicate SEM.

\section{Discussion}

To determine the role of hippocampal CREB in behaviors associated with depression, anxiety, and antidepressant response, we used a mouse in which CREB was deleted specifically in this region, beginning in adulthood. Despite robust and significant loss of CREB in the hippocampus, we found no effect of this restricted loss on baseline anxiety-like behavior or response to acute antidepressants in the forced swim test. Additionally, deletion of CREB in the hippocampus did not affect response to chronic antidepressant treatment in the novelty-induced hypophagia procedure. However, loss of hippocampal CREB allowed for a response to short-term antidepressant treatment in this test, which is not observed in wild-type animals. This accelerated response to antidepressant treatment was associated with increased levels of hippocampal neurogenesis. The deletion of CREB in the hippocampus also led to upregulation of a CREB-family protein, CREM, though the CREM repressor isoform ICER was unchanged. Overexpression of the CREM activator isoform CREM $\tau$ in the hippocampus was sufficient to recapitulate the phenotype of hippocampal CREB deletion in the novelty-induced hypophagia procedure, allowing for an accelerated response to antidepressants in this test. CREM $\tau$ overexpression was also sufficient to cause an increase in hippocampal neurogenesis of a similar magnitude to that seen following CREB deletion. These findings implicate CREM $\tau$ as an important transcription factor that may
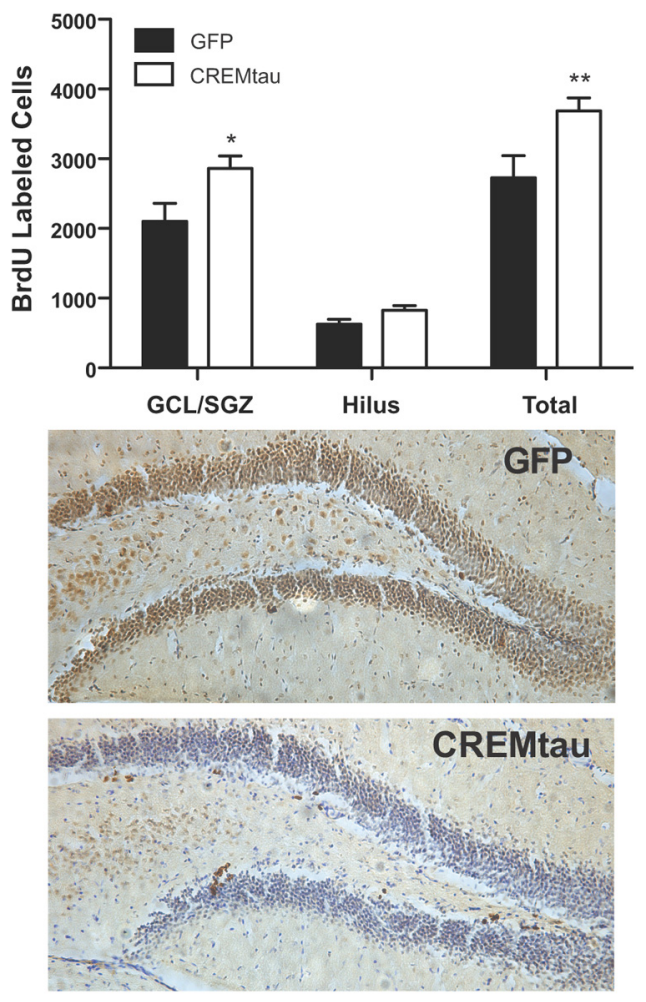

Figure 10. Overexpression of CREM $\tau$ in the hippocampus causes significant increase in hippocampal neurogenesis. Quantification of the number of BrdU-labeled cells in the dentate gyrus $\mathrm{GCL} / \mathrm{SGZ}$ and hilus are shown. Example images of the DG from AAV-GFP-injected animals (middle) and AAV-CREM $\tau$-injected animals (bottom) after staining with anti-BrdU antibody (brown) and counterstaining with cresyl violet (purple) are shown. Mice were killed $24 \mathrm{~h}$ following a single injection of BrdU. There was a significant increase in BrdU-labeled cells in the GCL/SGZ, but not the hilus, of AAV-CREM $\tau$-injected mice compared with AAV-GFP-injected mice, indicating an increase in cell proliferation $(n=12) .{ }^{*} p<0.05$ versus AAV-GFP-injected controls; ${ }^{* *} p<0.01$ versus AAV-GFP-injected controls. Error bars indicate SEM.

identify unique targets to accelerate the therapeutic response of traditional antidepressants.

\section{Selective deletion of CREB in the hippocampus leads to increased anxiety in the novelty-induced hypophagia procedure that is not generalized}

In the current study, we demonstrate that selective deletion of CREB in the hippocampus is sufficient to induce an increase in anxiety-like behavior in the novelty-induced hypophagia procedure, as indicated by an increase in latency to feed in the novel environment. This is consistent with what is seen in $\mathrm{CREB}^{\alpha \Delta}$ mice in this task (Gur et al., 2007), providing further evidence for a specific role for the hippocampus in this form of anxiety-like behavior. In contrast, we did not see a generalized anxiety phenotype in other tests of anxiety-like behavior (elevated zero maze, marble burying), nor did we see an "antidepressant" phenotype in the forced swim or tail suspension tests. This is in sharp contrast to other models of global deletion of CREB, which demonstrate a more general increase in anxiety-like behavior as well as an antidepressant phenotype in these tasks (Conti et al., 2002; Gur et al., 2007; Mombereau et al., 2010). Although these differences between the $\mathrm{CREB}^{\alpha \Delta}$ mice and specific hippocampal CREB deletion could be due to developmental effects or the fact that here we did not completely ablate CREB expression in the hippocampus, it is more likely that these behavioral phenotypes are mediated by CREB in different brain regions. For example, CREB activity within the amygdala is thought to play a critical role in 
anxiety behavior (Pandey et al., 2005). Additionally, CREB targets within the amygdala, such as neuropeptide $\mathrm{Y}$ and corticotrophin-releasing factor, are potent mediators of anxiety behavior (Pandey, 2003; Pandey et al., 2005; Zhang et al., 2010; Gilpin, 2012).

Selective deletion of CREB in the hippocampus is sufficient to accelerate antidepressant response and increase neurogenesis We demonstrate that in the novelty-induced hypophagia procedure, selective deletion of CREB in the hippocampus leads to a reduction in latency to consume in the novel environment following acute treatment with DMI, a tricyclic antidepressant. This is in contrast to wild-type mice that only respond to chronic DMI treatment in this procedure. This response to a shorter course of antidepressants is identical to what is seen in $\mathrm{CREB}^{\alpha \Delta}$ mice (Gur et al., 2007). These results suggest that the hippocampus is an important locus for determining behavior in the novelty-induced hypophagia procedure, particularly the influence of CREB on this behavior.

Additionally, our results provide further evidence correlating the amount of hippocampal neurogenesis and the antidepressant response in the novelty-induced hypophagia procedure. In 129/ SvEv and C57BL/6 mice, the antidepressant-induced increase in hippocampal neurogenesis is necessary for the behavioral response to chronic antidepressant treatment in the noveltysuppressed feeding procedure (Santarelli et al., 2003; David et al., 2009), which is very similar to the novelty-induced hypophagia procedure used here. However, in BALB/c7 mice, the behavioral effects of antidepressants do not appear to require hippocampal neurogenesis (Holick et al., 2008; Huang et al., 2008). If increased hippocampal neurogenesis or some other increase in hippocampal plasticity is necessary for the behavioral response to antidepressants, as many propose (Eisch et al., 2008; Snyder et al., 2011; Snyder and Cameron, 2012), it may be one cause for the lengthy time course of response, as only chronic, not acute, treatment with antidepressants causes increased hippocampal neurogenesis (Malberg et al., 2000). In this case, as with the $\mathrm{CREB}^{\alpha \Delta}$ mice, the increase in baseline levels of hippocampal neurogenesis may be "priming" the brain to respond to antidepressant treatment, allowing for an accelerated behavioral response. This is consistent with recent work demonstrating that lithium augmentation of traditional antidepressants leads to enhanced antidepressant response in the novelty-induced hypophagia procedure in treatment-resistant mice, and this behavioral response is correlated with increased neurogenesis in the hippocampus (O'Leary et al., 2013). Although the majority of work has focused on the hippocampus, neurogenesis and gliogenesis in other brain areas have also been implicated in antidepressant response (Kodama et al., 2004; Czéh et al., 2007; Ohira et al., 2013), and future work examining the role of CREB in these neuroplastic changes could provide further insight into novel treatment options.

\section{Selective deletion of CREB in the hippocampus of adult mice leads to an increase in CREM expression that can lead to an accelerated antidepressant response}

As chronic antidepressant treatment leads to an increase in hippocampal CREB expression (Nibuya et al., 1996), it may seem surprising that we demonstrate an accelerated antidepressant response following CREB deletion. However, this effect was first demonstrated in mice with a global knockout of CREB (Gur et al., 2007) and is recapitulated in this hippocampal-specific deletion. This seeming discrepancy further suggests that the behavioral changes seen following CREB deletion may be due to an overex- pression of the related transcription factor, CREM. Upregulation of CREM, which is believed to compensate for CREB, is observed in other models in which CREB expression is reduced (Hummler et al., 1994; Mantamadiotis et al., 2002; Balschun et al., 2003; Valverde et al., 2004). In the current study, we demonstrate that increased CREM expression occurs even when CREB is deleted in adulthood. The fact that we observe increased expression of CREM only 8 weeks after injection of a Cre-expressing virus in the hippocampi of $\mathrm{Creb}^{\text {loxPlloxP }}$ mice suggests that the mechanisms responsible for such compensatory changes are much more dynamic than previously believed. Perhaps more interestingly, the isoform of CREM that is upregulated following hippocampal CREB deletion is not the ICER, the main CREM family protein in the brain (Mellström et al., 1993). While CREM $\tau$, the main isoform of CREM with transcriptional activator activity, is not expressed at high levels in the brain under normal conditions (Foulkes et al., 1992; Mellström et al., 1993), it may be involved in transcriptional activation in the absence of CREB, as has been seen in a cancer cell line that lacks CREB (Groussin et al., 2000). That upregulation of CREM $\tau$ may mediate the phenotype observed following CREB deletion is supported by the fact that overexpression of CREM $\tau$ was sufficient to recapitulate the accelerated antidepressant response and the increase in hippocampal neurogenesis seen following hippocampal CREB deletion. These findings are the first evidence that CREM $\tau$ in the brain can play a role in the behavioral responses to antidepressant treatment. While both CREB and CREM are known to bind to the perfect dyad symmetrical sequence TGACGTCA in vitro, target occupancy may differ between the two factors in vivo, or may occur in response to specific regulatory signals. Furthermore, there is some evidence that CREM $\tau$ may bind to unique (non-CRE) promoter sites to modulate transcription (Sasamori et al., 2008). Future work delineating CREM $\tau$ targets responsible for this accelerated antidepressant response could provide unique therapeutic targets for depression.

\section{Conclusion}

Selective CREB deletion within the hippocampus of adult mice led to an accelerated antidepressant response that was accompanied by an increase in hippocampal neurogenesis. CREB deletion in the hippocampus increased CREM expression, which was sufficient to cause the behavioral and cellular effects observed. This is the first report of a behavioral role for CREM $\tau$ within the brain. While CREB and CREM $\tau$ can both bind to and activate CREtarget genes, there are likely distinct target genes that are differentially regulated by these proteins. Future work identifying CREM targets may provide an avenue for research aimed at accelerating the therapeutic response to antidepressant treatment.

\section{References}

Ahmed BY, Chakravarthy S, Eggers R, Hermens WT, Zhang JY, Niclou SP, Levelt C, Sablitzky F, Anderson PN, Lieberman AR, Verhaagen J (2004) Efficient delivery of Cre-recombinase to neurons in vivo and stable transduction of neurons using adeno-associated and lentiviral vectors. BMC Neurosci 5:4. CrossRef Medline

Balschun D, Wolfer DP, Gass P, Mantamadiotis T, Welzl H, Schütz G, Frey JU, Lipp HP (2003) Does cAMP response element-binding protein have a pivotal role in hippocampal synaptic plasticity and hippocampusdependent memory? J Neurosci 23:6304-6314. Medline

Barrot M, Olivier JD, Perrotti LI, DiLeone RJ, Berton O, Eisch AJ, Impey S, Storm DR, Neve RL, Yin JC, Zachariou V, Nestler EJ (2002) CREB activity in the nucleus accumbens shell controls gating of behavioral responses to emotional stimuli. Proc Natl Acad Sci U S A 99:11435-11440. CrossRef Medline

Blom JM, Tascedda F, Carra S, Ferraguti C, Barden N, Brunello N (2002) 
Altered regulation of CREB by chronic antidepressant administration in the brain of transgenic mice with impaired glucocorticoid receptor function. Neuropsychopharmacology 26:605-614. CrossRef Medline

Carlezon WA Jr, Duman RS, Nestler EJ (2005) The many faces of CREB. Trends Neurosci 28:436-445. CrossRef Medline

Cearley CN, Wolfe JH (2006) Transduction characteristics of adenoassociated virus vectors expressing cap serotypes 7, 8, 9, and Rh10 in the mouse brain. Mol Ther 13:528-537. CrossRef Medline

Chen AC, Shirayama Y, Shin KH, Neve RL, Duman RS (2001) Expression of the cAMP response element binding protein (CREB) in hippocampus produces an antidepressant effect. Biol Psychiatry 49:753-762. CrossRef Medline

Conti AC, Cryan JF, Dalvi A, Lucki I, Blendy JA (2002) cAMP response element-binding protein is essential for the upregulation of brain-derived neurotrophic factor transcription, but not the behavioral or endocrine responses to antidepressant drugs. J Neurosci 22:3262-3268. Medline

Cryan JF, Markou A, Lucki I (2002) Assessing antidepressant activity in rodents: recent developments and future needs. Trends Pharmacol Sci 23:238-245. CrossRef Medline

Czéh B, Müller-Keuker JI, Rygula R, Abumaria N, Hiemke C, Domenici E, Fuchs E (2007) Chronic social stress inhibits cell proliferation in the adult medial prefrontal cortex: hemispheric asymmetry and reversal by fluoxetine treatment. Neuropsychopharmacology 32:1490-1503. CrossRef Medline

David DJ, Samuels BA, Rainer Q, Wang JW, Marsteller D, Mendez I, Drew M, Craig DA, Guiard BP, Guilloux JP, Artymyshyn RP, Gardier AM, Gerald C, Antonijevic IA, Leonardo ED, Hen R (2009) Neurogenesisdependent and -independent effects of fluoxetine in an animal model of anxiety/depression. Neuron 62:479-493. CrossRef Medline

Dowlatshahi D, MacQueen GM, Wang JF, Young LT (1998) Increased temporal cortex CREB concentrations and antidepressant treatment in major depression. Lancet 352:1754-1755. CrossRef Medline

Dulawa SC, Hen R (2005) Recent advances in animal models of chronic antidepressant effects: the novelty-induced hypophagia test. Neurosci Biobehav Rev 29:771-783. CrossRef Medline

Eisch AJ, Cameron HA, Encinas JM, Meltzer LA, Ming GL, OverstreetWadiche LS (2008) Adult neurogenesis, mental health, and mental illness: hope or hype? J Neurosci 28:11785-11791. CrossRef Medline

Foulkes NS, Mellström B, Benusiglio E, Sassone-Corsi P (1992) Developmental switch of CREM function during spermatogenesis: from antagonist to activator. Nature 355:80-84. CrossRef Medline

Frazer A (1997) Pharmacology of antidepressants. J Clin Psychopharmacol 17 [Suppl 1]:2S-18S. Medline

Frechilla D, Otano A, Del Río J (1998) Effect of chronic antidepressant treatment on transcription factor binding activity in rat hippocampus and frontal cortex. Prog Neuropsychopharmacol Biol Psychiatry 22:787-802. CrossRef Medline

Gao N, LeLay J, Vatamaniuk MZ, Rieck S, Friedman JR, Kaestner KH (2008) Dynamic regulation of Pdx1 enhancers by Foxal and Foxa2 is essential for pancreas development. Genes Dev 22:3435-3448. CrossRef Medline

Gass P, Riva MA (2007) CREB, neurogenesis and depression. Bioessays 29: 957-961. CrossRef Medline

Gilpin NW (2012) Corticotropin-releasing factor (CRF) and neuropeptide $\mathrm{Y}$ (NPY): effects on inhibitory transmission in central amygdala, and anxiety- and alcohol-related behaviors. Alcohol 46:329-337. CrossRef Medline

Graves L, Dalvi A, Lucki I, Blendy JA, Abel T (2002) Behavioral analysis of CREB alphadelta mutation on a B6/129 F1 hybrid background. Hippocampus 12:18-26. CrossRef Medline

Green TA, Alibhai IN, Hommel JD, DiLeone RJ, Kumar A, Theobald DE, Neve RL, Nestler EJ (2006) Induction of inducible cAMP early repressor expression in nucleus accumbens by stress or amphetamine increases behavioral responses to emotional stimuli. J Neurosci 26:8235-8242. CrossRef Medline

Groussin L, Massias JF, Bertagna X, Bertherat J (2000) Loss of expression of the ubiquitous transcription factor cAMP response element-binding protein (CREB) and compensatory overexpression of the activator CREMtau in the human adrenocortical cancer cell line H295R. J Clin Endocrinol Metab 85:345-354. CrossRef Medline

Gur TL, Conti AC, Holden J, Bechtholt AJ, Hill TE, Lucki I, Malberg JE, Blendy JA (2007) cAMP response element-binding protein deficiency allows for increased neurogenesis and a rapid onset of antidepressant response. J Neurosci 27:7860-7868. CrossRef Medline

Holick KA, Lee DC, Hen R, Dulawa SC (2008) Behavioral effects of chronic fluoxetine in $\mathrm{BALB} / \mathrm{cJ}$ mice do not require adult hippocampal neurogenesis or the serotonin 1A receptor. Neuropsychopharmacology 33:406417. CrossRef Medline

Huang GJ, Bannerman D, Flint J (2008) Chronic fluoxetine treatment alters behavior, but not adult hippocampal neurogenesis, in BALB/cJ mice. Mol Psychiatry 13:119-121. CrossRef Medline

Hummler E, Cole TJ, Blendy JA, Ganss R, Aguzzi A, Schmid W, Beermann F, Schütz G (1994) Targeted mutation of the CREB gene: compensation within the CREB/ATF family of transcription factors. Proc Natl Acad Sci U S A 91:5647-5651. CrossRef Medline

Kaspar BK, Vissel B, Bengoechea T, Crone S, Randolph-Moore L, Muller R, Brandon EP, Schaffer D, Verma IM, Lee KF, Heinemann SF, Gage FH (2002) Adeno-associated virus effectively mediates conditional gene modification in the brain. Proc Natl Acad Sci U S A 99:2320-2325. CrossRef Medline

Klein RL, Dayton RD, Tatom JB, Henderson KM, Henning PP (2008) AAV8, 9, Rh10, Rh43 vector gene transfer in the rat brain: effects of serotype, promoter and purification method. Mol Ther 16:89-96. CrossRef Medline

Kodama M, Fujioka T, Duman RS (2004) Chronic olanzapine or fluoxetine administration increases cell proliferation in hippocampus and prefrontal cortex of adult rat. Biol Psychiatry 56:570-580. CrossRef Medline

Kyrmizi I, Hatzis P, Katrakili N, Tronche F, Gonzalez FJ, Talianidis I (2006) Plasticity and expanding complexity of the hepatic transcription factor network during liver development. Genes Dev 20:2293-2305. CrossRef Medline

Laifenfeld D, Karry R, Grauer E, Klein E, Ben-Shachar D (2005) Antidepressants and prolonged stress in rats modulate CAM-L1, laminin, and pCREB, implicated in neuronal plasticity. Neurobiol Dis 20:432-441. CrossRef Medline

Lemberger T, Parkitna JR, Chai M, Schütz G, Engblom D (2008) CREB has a context-dependent role in activity-regulated transcription and maintains neuronal cholesterol homeostasis. FASEB J 22:2872-2879. CrossRef Medline

Lucki I (2001) A prescription to resist proscriptions for murine models of depression. Psychopharmacology (Berl) 153:395-398. CrossRef Medline

Malberg JE, Eisch AJ, Nestler EJ, Duman RS (2000) Chronic antidepressant treatment increases neurogenesis in adult rat hippocampus. J Neurosci 20:9104-9110. Medline

Manier DH, Shelton RC, Sulser F (2002) Noradrenergic antidepressants: does chronic treatment increase or decrease nuclear CREB-P? J Neural Transm 109:91-99. CrossRef Medline

Mantamadiotis T, Lemberger T, Bleckmann SC, Kern H, Kretz O, Martin Villalba A, Tronche F, Kellendonk C, Gau D, Kapfhammer J, Otto C, Schmid W, Schütz G (2002) Disruption of CREB function in brain leads to neurodegeneration. Nat Genet 31:47-54. CrossRef Medline

Mellström B, Naranjo JR, Foulkes NS, Lafarga M, Sassone-Corsi P (1993) Transcriptional response to cAMP in brain: specific distribution and induction of CREM antagonists. Neuron 10:655-665. CrossRef Medline

Merali Z, Levac C, Anisman H (2003) Validation of a simple, ethologically relevant paradigm for assessing anxiety in mice. Biol Psychiatry 54:552565. CrossRef Medline

Mombereau C, Gur TL, Onksen J, Blendy JA (2010) Differential effects of acute and repeated citalopram in mouse models of anxiety and depression. Int J Neuropsychopharmacol 13:321-334. CrossRef Medline

Nair A, Vaidya VA (2006) Cyclic AMP response element binding protein and brain-derived neurotrophic factor: molecules that modulate our mood? J Biosci 31:423-434. CrossRef Medline

Nestler EJ, Barrot M, DiLeone RJ, Eisch AJ, Gold SJ, Monteggia LM (2002) Neurobiology of depression. Neuron 34:13-25. CrossRef Medline

Nibuya M, Nestler EJ, Duman RS (1996) Chronic antidepressant administration increases the expression of cAMP response element binding protein (CREB) in rat hippocampus. J Neurosci 16:2365-2372. Medline

Ohira K, Takeuchi R, Shoji H, Miyakawa T (2013) Fluoxetine-induced cortical adult neurogenesis. Neuropsychopharmacology 38:909-920. CrossRef Medline

O'Leary OF, Zandy S, Dinan TG, Cryan JF (2013) Lithium augmentation of the effects of desipramine in a mouse model of treatment-resistant 
depression: a role for hippocampal cell proliferation. Neuroscience 228:36-46. CrossRef Medline

Pandey SC (2003) Anxiety and alcohol abuse disorders: a common role for CREB and its target, the neuropeptide Y gene. Trends Pharmacol Sci 24:456-460. CrossRef Medline

Pandey SC, Zhang H, Roy A, Xu T (2005) Deficits in amygdaloid cAMPresponsive element-binding protein signaling play a role in genetic predisposition to anxiety and alcoholism. J Clin Invest 115:2762-2773. CrossRef Medline

Pliakas AM, Carlson RR, Neve RL, Konradi C, Nestler EJ, Carlezon WA Jr (2001) Altered responsiveness to cocaine and increased immobility in the forced swim test associated with elevated cAMP response elementbinding protein expression in nucleus accumbens. J Neurosci 21:73977403. Medline

Porsolt RD, Brossard G, Hautbois C, Roux S (2001) Rodent models of depression: forced swimming and tail suspension behavioral despair tests in rats and mice. Curr Protoc Neurosci Chapter 8:Unit 8.10A. CrossRef Medline

Santarelli L, Saxe M, Gross C, Surget A, Battaglia F, Dulawa S, Weisstaub N, Lee J, Duman R, Arancio O, Belzung C, Hen R (2003) Requirement of hippocampal neurogenesis for the behavioral effects of antidepressants. Science 301:805-809. CrossRef Medline

Sasamori E, Shimoyama S, Fukushige S, Kikuchi H (2008) Involvement of CREM in CYP1A1 induction through ligand-independent activation pathway of aryl hydrocarbon receptor in HepG2 cells. Arch Biochem Biophys 478:26-35. CrossRef Medline

Seri B, García-Verdugo JM, McEwen BS, Alvarez-Buylla A (2001) Astrocytes give rise to new neurons in the adult mammalian hippocampus. J Neurosci 21:7153-7160. Medline

Shin S, Le Lay J, Everett LJ, Nagel K, McKenna L, Branswig N, Gupta R, Rafiq
K, Kaestner KH (2013) Deletion of CREB impairs islet architecture and beta-cell survival. J Clin Invest, in press.

Snyder JS, Cameron HA (2012) Could adult hippocampal neurogenesis be relevant for human behavior? Behav Brain Res 227:384-390. CrossRef Medline

Snyder JS, Soumier A, Brewer M, Pickel J, Cameron HA (2011) Adult hippocampal neurogenesis buffers stress responses and depressive behaviour. Nature 476:458-461. CrossRef Medline

Tardito D, Perez J, Tiraboschi E, Musazzi L, Racagni G, Popoli M (2006) Signaling pathways regulating gene expression, neuroplasticity, and neurotrophic mechanisms in the action of antidepressants: a critical overview. Pharmacol Rev 58:115-134. CrossRef Medline

Thome J, Sakai N, Shin K, Steffen C, Zhang YJ, Impey S, Storm D, Duman RS (2000) cAMP response element-mediated gene transcription is upregulated by chronic antidepressant treatment. J Neurosci 20:4030-4036. Medline

Valverde O, Mantamadiotis T, Torrecilla M, Ugedo L, Pineda J, Bleckmann S, Gass P, Kretz O, Mitchell JM, Schütz G, Maldonado R (2004) Modulation of anxiety-like behavior and morphine dependence in CREBdeficient mice. Neuropsychopharmacology 29:1122-1133. CrossRef Medline

Wallace TL, Stellitano KE, Neve RL, Duman RS (2004) Effects of cyclic adenosine monophosphate response element binding protein overexpression in the basolateral amygdala on behavioral models of depression and anxiety. Biol Psychiatry 56:151-160. CrossRef Medline

Wong ML, Licinio J (2001) Research and treatment approaches to depression. Nat Rev Neurosci 2:343-351. CrossRef Medline

Zhang H, Sakharkar AJ, Shi G, Ugale R, Prakash A, Pandey SC (2010) Neuropeptide $\mathrm{Y}$ signaling in the central nucleus of amygdala regulates alcohol-drinking and anxiety-like behaviors of alcohol-preferring rats. Alcohol Clin Exp Res 34:451-461. CrossRef Medline 